\title{
Governo Sarney: dilemas e virtudes de uma transição negociada
}

Rachel Meneguello

UnIVERSIDAD DE Campinas, BRasIL

Pese a las trabas que impuso la reforma del Estado, dentro de la transición los partidos retomaron un lugar central en el desarrollo de los procesos políticos. Al analizar el gobierno de Sarney, se pone énfasis en cambios institucionales: la reforma partidaria de 1985 y la Constitución de 1988. Se examinan los límites de la relación entre ejecutivo y legislativo, en especial en el papel de la composición del federal, y se aborda la búsqueda de la gobernabilidad, marcada por una simbiosis entre estabilidad del régimen y reformas políticas.

\section{APRESENTAÇÃO}

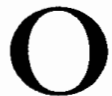

caráter híbrido das transições latino-americanas define um cenário em que, ao lado da incapacidade em solucionar a dívida social legada pelo autoritarismo, ocorrem avanços institucionais concretos. Embora a ampliação da cidadania não possa ser pensada sem a avaliação dos marcos da pobreza e da exclusão, a reflexão sobre as transformações político-institucionais nesses países mostra avanços no processo de democratização. O argumento de que o desenvolvimento de procedimentos democráti- cos traduz as formas de expansão do neoliberalismo, convivindo perfeitamente bem com eleições e formas participativas de organização e decisão, não deve obscurecer importantes conquistas no campo político-representativo e das garantias institucionais, as quais vêm promovendo patamares consideráveis de intervenção dos agentes sociais no espaço público.

Os limites deste trabalho esão dados pela análise dos aspectos institucionais do governo Sarney (1985-1989). Primeiramente, apresento os aspectos principais de mudança no sistema político desenvolvidos logo no início do 
governo. Em seguida, apresento as principais reformas institucionais e os limites da relação entre os poderes excutivo e legislativo. Finalmente, trato da forma que tomou a busca de governabilidade neste período marcado pela simbiose entre a estabilidade do regime e as reformas econômicas.

O ponto central é mostrar que dentre as principais inovações políticas da transição, os partidos políticos readquiriram lugar central no desenvolvimento dos processos políticos.

\section{INTRODUÇÃO: MARCOS DA REFLEXÃO SOBRE A CONSTRUÇÃO DEMOCRÁTICA E O PAPEL DOS PARTIDOS}

A reflexão sobre o desenvolvimento dos partidos orienta-se pelos dilemas que contrapóem as transformações do sistema político ao desempenho das organizaçôes frente às novas alternativas de representação, à sua capacidade de gestâo das sociedades e à adaptação ao cenário contemporâneo. Um dos principais pontos que a caracterizam é a firme crítica que aponta o declínio dos partidos pela degeneração das suas funções de representar e articular interesses; das bases de organização que traduzem os vínculos com o eleitorado, e ainda, pela inadequação frente aos novos interesses e questóes emergidos no sistema político. ${ }^{1}$

As mudanças no campo da representação política contribuem com essa

${ }^{1}$ Pizzorno, Interests, 1981; Baldasarre, L'evoluzione,1983; Evers, Costas, 1983, vol. 2, núm. 1; Lawson e Merkl, Parties, 1988, especialmente Lawson, "Linkage", pp. 13-38. visão. As novas condições do relacionamento entre o eleitor e o político, marcado pela ação dominante dos meios de comunicação de massa, priorizam o personalismo e a imagem e prescindem da mediação partidária. Da mesma forma, o processo de formação das preferências políticas passa a buscar parâmetros em um amplo campo homogêneo de informações, através do qual dá-se a percepção das questões e temas públicos, e não a partir de linhas de opinião estruturadas sobre clivagens ou interesses específicos organizados, estabelecidos tradicionalmente pelas organizações partidárias. A perda pelos partidos do monopólio da organização e representação traduz o dilema da representação política na sociedade contemporânea, na qual esses processos emergem redefinidos pela constituição de um público de massa informado. ${ }^{2}$

No entanto, no campo dos processos decisórios e da gestão da sociedade, os partidos figuram como agentes centrais da conexão entre os cidadãos e os governos democráticos, atuando como os articuladores das questões na arena pública, definindo agendas governamentais e influenciando o processo de elaboração das políticas públicas. Partidos com sustentação eleitoral participam da composição dos governos e estabelecem as bases para a relação entre os poderes executivo e legislativo. ${ }^{3}$

\footnotetext{
${ }^{2}$ Ginsberg, Captive, 1986; Manin, Metamorfoses, 1995.

${ }^{3}$ Budge e Keman, Parties, 1990; Shefter, Political, 1994; Klingemann, Hofferbert e Budge, Parties, 1994.
} 
Nessa direção, a análise de experiências recentes de governo apontam que as relações entre os partidos e o Estado estabelecem um padrão redimensionado de decisões de políticas públicas e constituem um importante locus de sustentação e de legitimação das organizações, promovendo uma significativa alteração no seu perfil em direção à redefinição e à priorização das suas funções. $O$ Estado adquiriu um papel crescente como elemento regulador da vida e do funcionamento dos partidos e sua participação governamental vem ampliando as bases de seu desenvolvimento através dos recursos políticos ali produzidos. ${ }^{4}$

Partidos políticos estão considerados aqui com base em duas acepções. A primeira diz respeito às suas funções representativa e de articulação de interesses, segundo as quais, em que pesem as transformações da representação política, estas são as instituições que, através da competição eleitoral, melhor integram clientelas, mobilizam eleitorados, conferem amplitude aos interesses populares na política e estruturam as vontades e demandas no sistema competitivo. ${ }^{5}$

A segunda refere-se à sua função governativa, na qual sobressaem como os principais agentes dos processos governamentais: partidos formam governos, ocupam cargos e produzem políticas públicas, pelas quais operam a responsividade das instâncias deci-

${ }^{4}$ Katz e Mair, Parties, 1994.

5 Wilson, Parties, 1988; Farneti, Partiti, 1986; Harmel e Robertson, Formation, 1985, vol. 6 , núm. 4 . sórias à sociedade, produzindo governabilidade. ${ }^{6}$

Partidos e governos democráticos, portanto, são indissociáveis pela garantia da responsividade à sociedade $\mathrm{e}$ imprescindíveis ao seu funcionamento. É no quadro dessa perspectiva de análise que a análise do papel dos partidos no período inicial da transição brasileira se estabelece.

Colocada no cenário das transições democráticas, essa reflexão adquire tonalidade mais forte.

A construção de contextos institucionais que (re)introduzem a idéia de bom governo no novo regime democrático conferiu centralidade na agenda das transições à democracia política e à constituição de arranjos institucionais. $^{7}$

O bom governo está entendido aqui como a capacidade de gerar políticas, procedimentos e decisões dirigidos à solução do legado autoritário. ${ }^{8}$ Assim, para a o caso brasileiro, as reformas institucionais e a conseqüente reintrodução de atores políticos na cena pública é, desde o início da transição, condição inquestionável da constituição de um padrão democrático de relacionamento entre a sociedade e o Estado.

No primeiro governo democrático, a reintrodução dos partidos na arena governamental e a intensificação da

\footnotetext{
${ }^{6}$ Pennock, Democratic, 1979; Budge e Keman, Parties, 1990; Shefter, Political, 1994; Klingemann, Hofferbert e Budge, Parties, 1994.

7 Malloy, "Política", 1993; World Bank, Governance, 1992; Diniz, "Governabilidade", 1995, vol. 38 , núm. 3 .

Torres-Rivas, Democracy, 1995.
} 
arena representativa desencadearam mudanças importantes no padrão de organização do sistema partidário.

Ocorreram mudanças no padrão de desenvolvimento institucional, em direção ao fortalecimento das agremiações; ocorreram mudanças no padrão de funcionamento partidário, segundo o qual a relação entre o executivo e o legislativo mostrou-se central à governabilidade.

EM BUSCA DO NOVO REGIME: O PREFÁCIO DAS MUDANÇAS

Já foi apontada em trabalho anterior a singularidade comparada do processo de transição brasileira frente aos países do Cone Sul que, durante os anos oitenta, também estabeleceram uma agenda de transformação política. ${ }^{9} \mathrm{Du}$ rabilidade e adaptação do regime militar no processo de liberalização foram os vetores que conduziram as mudanças institucionais e constituíram o diálogo possível com as forças de oposição.

No decorrer da chamada "abertura política pela via eleitoral", o quadro político dual estabelecido com a partilha de poder entre o PMDB -partido de oposição- e o PDS - partido do governo- nas eleiçôes diretas para os governos dos estados de $1982,{ }^{10}$ redimensionou a capacidade de articulação da oposição ao regime e já em 1983 abriu espaço para a canalização

\footnotetext{
${ }^{9}$ Meneguello, "Mudanças", 1996.

${ }^{10}$ Nas eleçóes gerais diretas de 1982, O PMDB ganhou o governo de dez estados; o PDS, nove, e o PDT, um governo.
}

das expectativas com o voto direto para a presidência da república na "Campanha das Diretas-já".

Considerado um dos maiores fenômenos de mobilização popular política do período recente, que abrangeu os partidos de oposição e os vários setores organizados da sociedade, a Campanha das Diretas desaguou no Congresso onde a derrota em 25 de abril de 1985 da emenda Dante de Oliveira, que estabelecia eleições diretas para presidente da república em 1984, selou os limites da transição para a democracia.

A bibliografia que analisa a conjuntura sucessória desenvolvida a partir de 1984 é consensual em apontar nos procedimentos institucionais e nas articulaçôes para a candidatura de Tancredo Neves os limites estreitos das transformações políticas que seriam conduzidas no novo período. ${ }^{11}$

O ponto de partida é a constatação de que o processo sucessório que pôs fim ao ciclo de presidentes militares iniciado em 1964 deu-se sobre as bases políticas e institucionais do regime autoritário.

Em primeiro lugar, com relação aos aspectos institucionais, o cenário da sucessão presidencial foi dado pela manutenção das regras estabelecidas pelo regime anterior. ${ }^{12}$ Embutidas no

11 Souza, "Espada", 1989; Salum Jr., Graeff e Martins, "Nova", 1986; Camargo e Diniz, Continuidade, 1989.

${ }^{12}$ Em 26 de abril de 1984 foi derrotada por votação no Congresso a proposta de realização de eleiçōes presidenciais diretas apresentada pela emenda Dante de Oliveira. Com isso ficou mantida a regra de eleição presidencial indireta através de Colégio Eleitoral. 
amplo programa de distensão lenta e gradual que marcou todo o processo de abertura política, as regras para a eleição presidencial indireta responderam ao cálculo da transição controlada. Não cabe aqui reproduzir textualmente as teses da volumosa bibliografia que trata das ações regulatórias do regime quanto à organização da arena representativa desde o início da "abertura política", ${ }^{13}$ mas cabe aos propósitos deste trabalho, afirmar a importância do cenário institucional que abrigou o desenvolvimento das negociações para a sucessão presidencial em 1985.

Pode-se afirmar que este foi um dos principais condicionantes da articulação da Aliança Democrática e da candidatura Tancredo Neves, um político de oposição moderada ao regime autoritário, e uma indicação considerada consensual para uma ampla gama de setores políticos. Tratava-se, em linhas gerais, da apresentação de uma proposta eleitoral ao mesmo tempo de garantia à transição a um governo civil, e de aceitação pelos setores dominantes políticos e militares.

Com a exceção do Partido dos Trabalhadores, formou-se no Congresso um consenso entre os partidos de oposição em torno do projeto de democratização encabeçado pelo PMDB. As articulações das forças políticas de oposição ao regime militar desenvolvidas desde a derrota da emenda das eleições diretas no Congresso, benefi-

${ }^{13}$ Destaco para representar esta bibliografia: Velasco e Cruz, "Castello", 1983; Lamounier, "Opening", 1984; Lamounier, "Apontamentos", 1985. ciaram-se da cisão interna ao PDS, partido do governo, provocada pela convenção para escolha do candidato à presidência. Esta cisão,-originada na oposição intra-partidária ao grupo de Paulo Maluf e à definição de sua candidatura à presidência, constituiu a Frente Liberal, agrupamento político majoritariamente identificado e composto de políticos do regime anterior, apoiadores da transição moderada. ${ }^{14}$

A oposição à candidatura de Paulo Maluf, político paulista, definiu-se sobretudo pelo conflito entre as bases políticas regionais internas ao PDS das regióes sudeste e nordeste, bases das principais lideranças do partido. Com essa candidatura, o desligamento de lideranças ampliou significativamente o leque de adesóes à fórmula de "conciliação nacional", preconizada pela Aliança Democrática, levando a que parte importante do PDS apoiasse a candidatura Tancredo Neves.

A proposta de transição ao novo regime foi apresentada à cena pública com o lançamento da Aliança Democrática em agosto de 1984, através do seu documento fundador "Compromisso com a Nação". Nele ficava estabelecida a coalizão entre a Frente Liberal e o PMDB, refletida no teor moderado das mudanças políticas, e traduzida na candidatura oficial de Tancredo Neves, pelo PMDB, e de José Sarney, pela Frente Liberal. ${ }^{15}$

${ }^{14}$ Em janeiro de 1985 a Frente Liberal tornou-se oficialmente o Partido da Frente LiberalPFL.

${ }^{15} \mathrm{O}$ documento "Compromisso com a Nação" foi lançado em 7 de agosto de 1984 e teve como signatários pelo PMDB, Ulysses Guimarães, então presidente do partido, e Tancredo 
O texto do documento deixa claro que os limites da mudança política estavam estabelecidos pela obtenção de confiança das forças dominantes do regime, e ilustra o processo de acomodação de interesses próprio às transiçōes negociadas. ${ }^{16}$

Assim, com um apelo ao patriotismo e ao compromisso com o interesse nacional, o documento elenca como princípio fundante do pacto político a conciliação baseada no não ressentimento:

Só a coesão nacional, em torno de valores comuns e permanentes, pode garantir a soberania do país, assegurar a paz, permitir o progresso econômico e promover a justiça social.

Este pacto político propugna a conciliação para a sociedade e o Estado, entre o povo e o governo. Sem ressentimentos, com os olhos voltados para o futuro, propõe o entendimento de todos os brasileiros.

É indispensável que se efetive o congraçamento nacional baseado na liberdade, na igualdade, na lei, no escrupuloso respeito pela coisa pública, na justa participação de todos nos frutos do progresso, na solidariedade entre os brasileiros. Congraçamento nacional capaz de propiciar um clima democrático, as mudanças que a nação reclama. (Documento "Compromisso com a nação", 7 de agosto de 1984.)

Neves, governador do estado de Minas Gerais, e pela Frente Liberal, Aureliano Chaves, então vice-presidente da república do governo do general Figueiredo, e Marco Maciel, senador do PDS, partido do governo, pelo estado de Pernambuco.

${ }^{16}$ Torre, "América", 1991.
No documento estão expostos os três pilares das mudanças preconizadas pela "Aliança", quais sejam, a organização institucional, a estabilização monetária e o resgate da dívida social. O campo institucional se destaca pelo anúncio de medidas, e é marcado pela convocação de assembléia para elaboração da nova constituição, pela reforma partidária e eleitoral e pela postura frente aos direitos e liberdades políti$\cos$, civis e sociais:

É urgente a necessidade de proceder-se a organização institucional do país.

Uma nova constituição fará do Estado, dos partidos políticos, meios voltados para a realização do homem sua dignidade, sua segurança e seu bem-estar.

O Brasil deve ser um pás para seu próprio povo, em que seja assegurado o exercício pleno da cidadania, respeitados os direitos humanos, reservadas a identidade e a cultura nacionais.

Em uma nação marcada pela pobreza e ameaçada pelo desespero tos marginalizados, a administração pública deve se caracterizar pela credibilidade e pela participação e se pautar sempre pela austeridade e moralidade. [...] Restabelecimento imediato das eleiçóes diretas, livres e com sufrágio universal, para presidente da república, prefeitos das capitais dos estados e dos municípios considerados estâncias hidrominerais e dos declarados de interesse da segurança nacional. Representação política de Brasília.

Convocação de constituinte, livre e soberana, em 1986, para elaboração de nova constituição.

Restabelecimento da independência e prerrogativas do poder legislativo e do poder judiciário; [...]

Reforma da legislação eleitoral de modo a possibilitar a formação de no- 


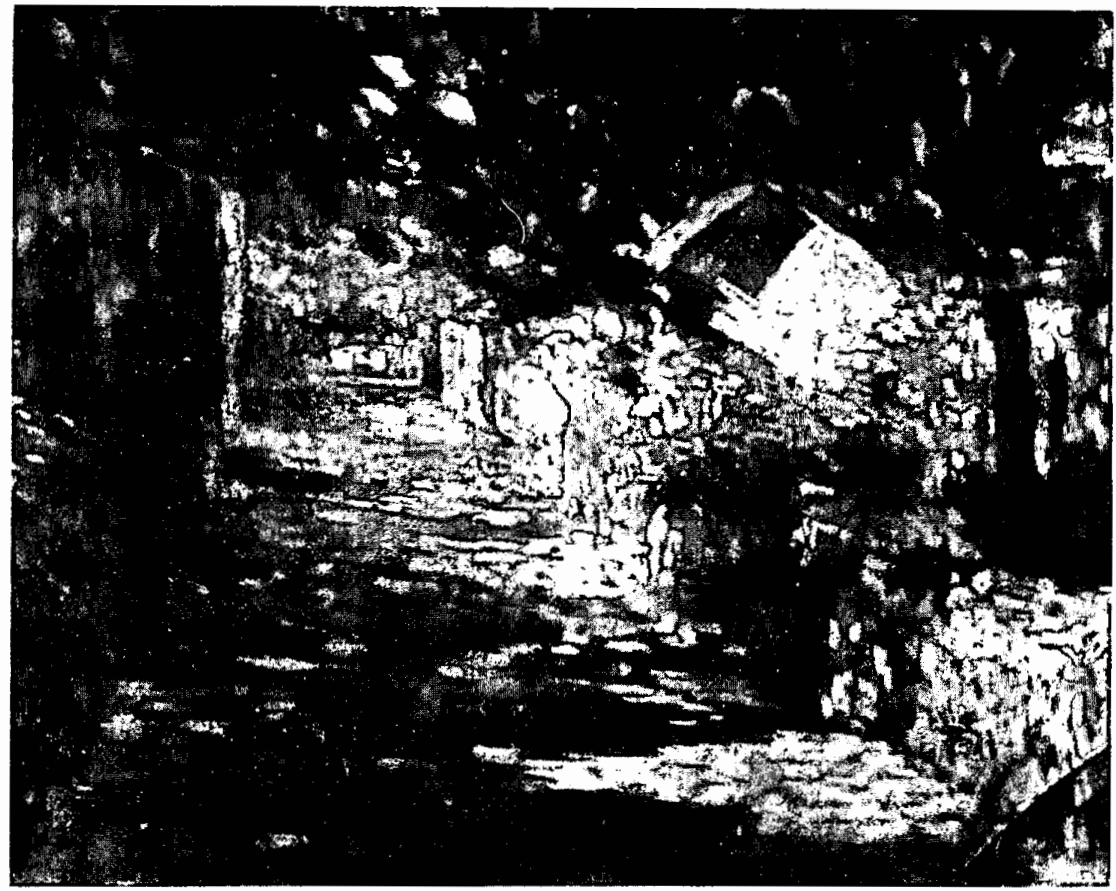

vos partidos, permitir as coligaçōes partidârias e assegurar às agremiaçōes políticas o acesso democrático ao rádio $\mathrm{e}$ à televisão; [...] Garantia da autonomia e liberdade sindicais e do direito de greve; $[. .$.$] Combate a qualquer espécie$ de discriminação e preconceito quanto à religiáo, sexo e raça. Proteção aos direitos das minorias; [...]

(Documento "Compromisso com a Nação", 7 de agosto de 1984.)

No campo econômico, fica traduzida a priorização das açóes dirigidas ao combate à inflação, estabilização econômica e desemprego:
Retomada e reordenamento do processo de desenvolvimento, como opção fundamental da sociedade brasileira; [...]

Combate à inflação, através de medidas considerem, não apenas sua origem financeira, mas sobretudo seu caráter prioritariamente social.

[...] Adoção de medidas de emergência contra a fome e o desemprego; [...]

(Documento "Compromisso com a Nação", 7 de agosto de 1984.)

Quanto ao resgate da dívida social, o documento menciona as ações bási- 
cas para recuperação dos patamares mínimos de bem-estar e dignidade, traduzidos nas políticas públicas sociais. No entanto, seria apenas com a promulgaçāo da nova constituição em 1988 que as condições do pacto social seriam edificadas:

É dever do Estado erradicar a miséria que afronta a dignidade nacional, assegurar a igualdade de oportunidades, propiciar melhor distribuição da renda e da riqueza, proporcionar o reencontro com os valores da nacionalidade. […]

Revisão da política salarial, com eliminação do processo de compressão do poder aquisitivo dos trabalhadores, dos servidores públicos e da classe média. $[\ldots]$ $[\ldots]$

Educação fundamental para todos.

Direcionamento de recursos e estímulos para o aumento substancial de oferta dos bens e serviços indispensáveis à satisfação das carências básicas da população no campo da alimen. tação, saúde, educação e trabalho; $[$...]

Melhoria da qualidade de vida e das condiçôes de segurança individual.

Reestruturação da previdência social e do sistema financeiro de habitação, com adoção de medidas, que lhes propiciem condiçōes de estabilidade e fidelidade aos objetivos sociais; [...]

Reforma agrária mediante cumprimento do Estatuto da Terra e melhoria das condiçôes de vida do homem do campo $[\ldots]$.

(Documento "Compromisso com a Nação", 7 de agosto de 1984.)

Um segundo ponto para a compreensão da dimensão dos limites da transição é a análise do processo eleitoral presidencial de 1985.
A definição da regra eleitoral indireta concentrou a questão sucessória no âmbito do Congresso entre os partidos envolvidos, à exceção dos partidos de esquerda, que mantiveram-se à margem das articulações políticas.

O desenvolvimento da dinâmica eleitoral nos limites do Congresso, como abrigo das principais articulações partidárias e negociaçóes para o lançamento das candidaturas, estabeleceu a dimensão limitada da participação popular nas transformaçóes correntes. O impacto dessa experiência definiu na expectativa pelo voto direto para a presidência a ponte para a cidadania plena.

Esse quadro teve um papel decisivo sobre os aspectos institucionais da noção de cidadania, bem como sobre a organização do quadro partidário no período seguinte.

A eleição presidencial foi realizada em 15 de janeiro, e ocorreu segundo processo indireto pelo Colégio Eleitoral composto pela totalidade do Congresso Nacional e mais seis deputados estaduais indicados pela bancada majoritária de cada estado. Do total de 686 votos, Tancredo Neves foi eleito contra Paulo Maluf com $70 \%$ dos votos (480).

É bastante clara a influência da lógica das eleições presidenciais indiretas e da coincidência entre as composiçóes do Colégio Eleitoral e do Congresso nas articulaçóes eleitorais e no quadro partidário. Esta dinâmica definiu a negociação prévia da maioria formada pelo PMDB e pelo PFL, que garantiu a vitória de Tancredo Neves e compôs a equipe de governo. A hegemonia da aliança PMDB-PFL na com- 
posição da equipe governamental de Tancredo e mantida durante todo o governo Sarney, e o predomínio desses partidos nas equipes dos governos federais em todo o período pós-85 são consequência direta dessa dinâmica.

\section{O GOVERNO SARNEY}

Marcado pela doença inesperada de Tancredo, o governo Sarney teve início com a posse na presidência da república em 15 de março de 1985, antecedendo em quase um mês a morte do então presidente eleito, ocorrida em 21 de abril. A posse de Sarney, antigo presidente do PDS, partido do governo militar, e novo membro da Frente Liberal não alterou os acordos políticos contraídos e expressos no documento da Aliança Democrática, mantendo a composição partidária do governo na coalizão PMDB-PFL.

De fato, algumas análises apontam na preservação das articulações das alianças políticas de Tancredo Neves uma indicação da falta de sustentação política pessoal do presidente Sarney diante da Aliança Democrática, sobretudo devido ao seu comprometimento político com o regime anterior. ${ }^{17}$

Faz parte desse cenário a situação dos militares. Até a promulgação da nova constituição em 1988, os militares mantiveram a capacidade efetiva de definir as transgressôes do jogo político, fundado numa situação legitimada pelos setores civis conservadores de apoio ao seu papel como redu-

${ }^{17}$ Sallum Jr., Graeff e Martins, "Nova", 1986; Sallum Jr., "Por quê", 1988. tores das tensốes sociais. Essa situação de "tutela cordial" ${ }^{18}$ traduzia o caráter negociado da transição e ilustrava a condução "sem ressentimentos" preconizada pelo manifesto da Aliança Democrática. Mais ainda, sua incorporação no novo regime deu-se pela manutenção de estruturas de funcionamento, como o sistema de informação (SNI), e pela presença de quadros no comando de empresas estatais estratégicas.

Este pacto de continuidade abrangeu diretamente os quadros tecnoburocráticos incorporados à estrutura estatal, mas o ponto máximo foi atingido com a nomeação da equipe ministerial de Tancredo Neves -mantida no início do governo Sarney- em que foram incorporados nos Ministérios da Fazenda e das Minas e Energia, respectivamente, o diretor da Receita Federal do governo militar logo anterior, e o vice-presidente da república do mesmo governo do Gen. Figueiredo.

Assim, na delicada conjuntura inicial, teve predomínio a orientação pela preservação do pacto de transição, traduzido na atenção sobre as reformas políticas já estabelecidas anteriormente no manifesto "Compromisso com a Nação".

A análise deste período mostra que somente um ano após a posse de Sarney foi dada tonalidade própria à sua administração. Ilustram essa nova condução as medidas econômicas, bem como a composição das equipes ministeriais.

Com o estatuto de primeiro governo democrático e combinando à carga

${ }^{10}$ Dreifuss, "Nova", 1986. 
conservadora característica, o governo Sarney foi marcado por uma sucessão de reformas na economia e no campo institucional.

Os pontos que destaco para ilustrar este período convergem para mostrar a centralidade dos partidos políticos na dinâmica dos processos de construção democrática.

\section{AS PRINCIPAIS REFORMAS INSTITUCIONAIS}

O governo Sarney abriga a construção das primeiras bases institucionais de legitimação do novo regime, durante o qual a etapa definitiva foi a convocação, em fins de 1985, da Assembléia Constituinte composta pelos parlamentares eleitos em 1986.

Traduzindo o documento fundador, no qual se afirmava a urgente a necessidade de proceder-se a organização institucional do país, a reforma da legislação eleitoral e partidária de 1985 foi a primeira ação do governo nessa direção. Dessa forma, embora o novo regime tenha adquirido formato definitivo com a promulgação da nova constituição de 1988 , desde sua inauguração é possível verificar como a questão partidária emerge no espaço de intersecção dos sistemas representativo e decisório.

Esta é uma distinção central com relação ao período anterior. De um lado, o Estado democrático recupera a dinâmica governativa dos partidos. De outro lado, definiu-se uma arena eleitoral de funcionamento vigoroso, caracterizada pela ampliação da competição política, do leque de organizações, dos graus de acesso eleitoral dire- to ao poder e pela frequência de eleições para diferentes cargos e níveis. Os primeiros anos -1985-1989- foram quase todos anos eleitorais, e desenvolveram-se com base na idéia do voto como um instrumento básico de organização e de afirmação da cidadlania. ${ }^{19}$

Aliado ao complexo cenário das transformações sócioeconômicas das últimas décadas, em que o crescimento e as transformações do perfil do eleitorado marcam a feição da questão democrática, ${ }^{20}$ este quadro institucional mobilizador definiu-se uma poderosa base para a participação e o apoio popular aos processos políticos.

\section{A primeira reforma}

A primeira reforma política do novo período -a Reforma Eleitoral e Partidária de maio de 1985-, foi apresentada sob o formato de emenda constitucional (Emenda $\left.{ }^{\circ} 25\right)$ e introduziu na legislação ampliações claras aos limites da cidadania política. Os principais pontos foram os seguintes: liber-

\footnotetext{
19 As eleiçōes realizadas no período foram: em 1985 -eleiçōes para as capitais; 1986 -eleiçōes gerais legislativas e para governos estaduais; 1988 -eleiçōes municipais; 1989 -eleições para presidente da república.

${ }^{20}$ Os processos de urbanização, industrializaçāo e as mudanças na força de trabalho são os principais vetores das transformações do eleitorado: entre 1970 e 1991 , a taxa de urbanização cresceu de $56 \%$ para $75.5 \%$; a força de trabalho ocupada no setor secundário cresceu de $12.4 \%$ para $23 \%$; no setor terciário, de $33 \%$ para $54.5 \%$, e no setor agrícola sofreu un decréscimo de 54\% para 23\%. Entre 1970 e 1990 o eleitorado cresceu de 28900000 para 90200000 eleitores. Anuário,1992.
} 
dade de organização partidária, incorporando os partidos comunistas e flexibilizando as regras organizacionais para pedido de registro; eleições diretas em dois turnos para presidente da república; eleições diretas em 1985 para prefeitos de capitais estaduais, áreas de segurança e estâncias hidrominerais, e o direito de voto aos analfabetos.

Assim, já no primeiro ano, o novo regime estabeleceu nas eleições para as capitais dos estados o primeiro momento amplo de avaliação popular da transição democrática. Os resultados eleitorais refletiram um apoio genérico ao PMDB -que elegeu 19 dos 24 prefeitos de capitais-, embora ali estivessem embutidas importantes divergências intra-partidárias, de natureza regional e ideológica, expressas através da eleição de lideranças locais, das quais boa parte estava definida à esquerda da configuração da Aliança Democrática. Assim, a eleição de lideranças políticas externas à coalizão de governo introduziu uma quebra parcial da sustentação ao governo previamente existente em alguns estados. ${ }^{21}$

Ao lado dos movimentos sociais e reivindicativos, o quadro partidário reemergiu na década de 1980 como importante canal de integração política, estabelecendo índices relativos altos de identificação no eleitorado. Por outro lado, este cenário partidário su-

${ }^{21}$ E exemplar o caso do município de São Paulo con a vitória de Jânio Quadros (PTB), dada a impossibilidade de reeleiçāo de Mário Covas, prefeito nomeado do PMDB. Um dos pontos da reforma eleitoral foi a proibição da reeleição dos prefeitos nomeados pelos governadores eleitos em 1982.

GOVERNO SARNEY: DILEMAS E VIRTUDES per-povoado de siglas teve também efeitos perversos sobre a dinâmica da competição eleitoral e da formação de tendências. Ao mesmo tempo em que ele traduziu a capacidade de mobilização de massa do sistema político, propiciou um ambiente favorável ao surgimento (e ressurgimento) de expressões carismáticas e personalistas, além da formação de alternativas populistas e pouco consolidadas, fatores potencialmente constrangedores ao forta. lecimento partidário. ${ }^{22}$ Esses traços básicos da política partidária nacional foram mantidos e reforçados nesse novo período.

\section{A nova constituição}

Em 1985, ano que precede a abertura do processo constituinte, teve lugar o trabalho de 50 membros nomeados pelo presidente da república para a elaboração de um projeto da nova constituição. Mais uma vez mostrando que as mudanças democráticas iniciais viriam pelo "alto", foi formada a Comissão Provisória de Estudos Constitucionais Afonso Arinos, ${ }^{23}$ denominada por setores críticos de "comissão de notáveis", incumbida de apresentar um ante-projeto constitucional a ser avaliado pelo Congresso eleito em novembro de 1986. Mesmo sem o apoio e a participação direta de setores centrais à transição, como os setores da esquerda, da Igreja e de importantes segmentos formadores de opinião, a

\footnotetext{
22 Souza, "España”, 1989.

${ }^{23}$ Afonso Arinos foi um decano do direito constitucional brasileiro.
} 
Comissão apresentou um projeto constitucional com avanços importantes no campo dos direitos políticos, civis e sociais, e na reorganização institucional. Este projeto foi parcialmente incorporado pelos trabalhos da Assembléia Constituinte, bem como na forma final do texto promulgado em 5 de outubro de 1988.

A Constituição Cidadã, tal como foi denominada no dia de sua promulgação por Ulysses Guimarães ${ }^{24}$ deu corpo legal ao pacto social, embora este estavivesse ainda por ser constituído pelas forças da transição.

A referência ao Pacto de Moncloa e às distinções para com o processo espanhol de transição é regular na análise comparativa da transição brasileira, e aqui cabe fazê-la. Diferentemente do caso espanhol, não ocorreu uma articulação bem sucedida de forças política e socialmente distintas em direção à elaboração do pacto social necessário à inauguração democrática. Assim, apenas com a Constituição de 1988 o necessário pacto social foi incorporado aos processos políticos, e o resgate da dívida social deu-se inicialmente sob a forma da lei, através da ampliação e universalização dos direitos sociais.

Neste campo, a nova constituição apresentou um novo modelo de proteção social, orientado pelos vetores da desburocratização e descentralização das políticas de saúde, educação, previdência e assistência social, ambos baluartes da democratização do Esta-

${ }^{26}$ Liderança histórica da oposição ao regime militar, presidente do PMDB e da Câmara de Deputados. do e da gestão pública. Anos mais tarde, na gestão do presidente Fernando Henrique Cardoso (1994-1998), as principais reformas constitucionais propostas pelo executivo seriam dirigidas a este campo, como estratégia de racionalização e controle dos gastos públicos.

$O$ resgate político deu-se, de um lado, pela manutenção das reformas estabelecidas já em 1985, através das regras de organização partidária e de participação, com a ampliação do direito ao voto e sobretudo a realização das eleiçōes diretas para presidente da república em 1989. O formato multipartidário conferiu um cenário númerico sem precedentes na história partidária do país, compondo um leque que chegou a 40 organizações com registro provisório ou definitivo.

Contudo, este cenário teve uma tradução limitada no Congresso Nacional. Apesar do grande número de legendas existentes, no período inicial o novo regime constitui-se um palco de representação congressual com no máximo cinco partidos com mais de $5 \%$ das cadeiras parlamentares. ${ }^{25}$ Esse cenário indicava que a dinâmica de organização dos partidos e a própria competição política exerciam um importante efeito regulador sobre o sistema partidário e sobre a composição de forças que funcionavam no primeiro governo democrático.

Nesse sentido, esta composição se destaca pela presença de partidos de todas as posições ideológicas -esquer$\mathrm{da} /$ centro/direita-, indicando a ampli-

${ }^{25}$ Sartori, Partidos, 1982. 
tude das bases congressuais, ${ }^{26}$ e pela presença no Congresso dos cinco partidos organizados com a Reforma Partidária de 1979 -PMDB, PDS, PTB, PDT, PT. Isto indica uma tendência a um fortalecimento partidário de âmbito nacional, bem como para a superação da intermitência das formações partidárias de períodos anteriores.

Os trabalhos constitucionais (19871988) foram decisivos para a organização do sistema partidário. $O$ debate ideológico imposto pela elaboração da nova Constituição produziu posicionamentos claros e permitiu definições mais precisas sobre a esquerda e a direita na país. Esse "exercício" contribuiu para que se definissem tendências substantivas, "expressas" através da formação de blocos e dissensões partidárias internas. ${ }^{27}$ Esse processo deu origem à formação do PSDB -Partido da Social-democracia Brasileira-, grupo formado pelos parlamentares situados internamente à esquerda no PMDB, e identificou o bloco conservador no Congresso, formado por parlamentares de várias agremiaçốes, e que recebeu o nome de "Centrão".

Também através da dinâmica dos trabalhos da Constituinte pode se observar a presença de importantes ele-

\footnotetext{
${ }^{26} \Lambda$ base para esta classificação está em trabalthos anteriores de diversos autores que trataran da questão ideológica do Congresso Nacional sob variados indicadores: Rodrigues, Quem, 1987; Kinzo, "Quadro", 1990, e DIAP, Quem, 1988. Em linhas gerais, esses estudos tomam como base o comportamento partidário durante a Assembléia Constituinte (1987-88) através de seu posicionamento frente a questôes políticas e sociais.

${ }^{27}$ Kinzo, "Cuadro", 1990.
}

mentos próprios ao funcionamento partidário, como níveis importantes de coesão e de diferenciação programática entre as agremiações, e que promoveram em alguns anos a definição de perfis político-ideológicos mais consistentes, fundados em um padrão ideológico de alianças. ${ }^{28}$

\section{Os limites da relação entre o executivo e o legislativo}

Entre 1985 e 1988, as muitas medidas econômicas tomadas pela presidência da república (sobre isso, vejamos o item seguinte) exemplificam o "decretismo" característico dos primeiros governos de transição latino-americana. ${ }^{29} \mathrm{~A}$ capacidade de governar por decretos-lei esteve garantida pela Constituição de 1967, para quando houvesse "urgência ou relevante interesse público" ${ }^{30}$ A Constituição de 1988 garante ao presidente a capacidade de editar a "medida provisória", que tem força imediata de lei e depende da apreciação do Congresso no prazo de 30 dias $^{31} \mathrm{~A}$ diferença entre as duas formas está em que, para a medida provisória, a não-manifestação do Congresso implica na perda do efeito legal da medida, o que confere um patamar de importancia ao Congresso e abre um caminbo de intervenção considerável do legislativo sobre as ações do executivo.

\footnotetext{
${ }^{28}$ Kinzo, Radiografia, 1993, cap. 4; Figueiredo e Limongi, "Terra", 1995.

29 Torre, "América", 1991.

${ }^{30}$ Constituição de 1967, art. 58.

${ }^{31}$ Constituição de 1988 , art. 62.
} 
Em que pese a evidência de que a continuidade não é absoluta, o fato a destacar está na manutenção das prerrogativas da presidência para legislar. Essa é a tendência ambivalente observada após a promulgação da Constituição de 1988: ao mesmo tempo em que permitiu a arena congressual recuperar grande parte da sua capacidade de intervenção retirada durante o regime militar, manteve os poderes legislativos obtidos pelo executivo durante o autoritarismo, gerando um padrão de produção legislativa no qual a presidência tem preponderância.

Assim, entre 1985 e 1988, não me. nos de $80 \%$ das iniciativas de lei foram apresentadas pelo executivo, e não mais que $30 \%$ tiveram origem do legislativo. Após a Constituiçăo de 1988, o patamar mínimo de leis apresentadas pelo executivo até 1989 é de aproximadamente $90 \%$, e para o legislativo, não mais que $20 \%{ }^{32}$

A produção legislativa de iniciativa exclusiva do executivo concentra-se, no período logo posterior à promulgação da Constituição, no campo orçamentário: do total da produção legislativa do ano de 1989 , de iniciativa do executivo e legislativo (279 leis sancionadas), $64.5 \%$ (180) foram oriundas do executivo. ${ }^{33}$

Embora este cenário desenhe um executivo proeminente, a interpretação de que o papel do Congresso é reduzido é equivocada. Entre 1985 e 1988, o cenário de dupla face, em que os decretos-lei convivem com os trabalhos constitucionais, mostra uma di-

32 Figueiredo e Limongi, "Mudança", 1995.

${ }^{33}$ Ibid. nâmica híbrida mas harmônica em que governabilidade e construção institucional estão marcadas por uma situação de crise e reforma. O Congresso funcionou como fiador das mudanças emergenciais articuladas fora dele e, ao mesmo tempo, foi o locus de dimensionamento ideológico e estruturação do quadro partidário.

O fato a destacar é que o contexto institucional das relaçóes entre o executivo e o legislativo do final do governo Sarney é inequivocamente diferente do contexto de 1985. A Constituição claramente expandiu os poderes legislativos e estabeleceu marcos de dependência para as ações da presidência da república.

Assim também é o panorama da organização do poder executivo neste governo. Vejamos o próximo item.

\section{O papel do Congresso na organização do executivo}

Estudar as relações entre os partidos $\mathrm{e}$ os governos significa identificar as áreas de intersecção entre os sistemas decisório e de representação em um sistema político democrático. Mais especificamente, significa identificar as formas de influência dos partidos na formação e no funcionamento dos governos, o grau de relaçōes existentes entre o poder executivo e o poder legislativo e a capacidade de representação dos governos frente ao tamanho das forças partidárias. Em suma, tratase de avaliar a capacidade de representar e de governar dos partidos.

Para a análise do governo Sarney, o ponto de partida é a constatação de 
que o processo de democratização iniciado em 1985 reintroduziu um elemento fundamental na dinâmica das relações entre os partidos e o Estado brasileiros, qual seja a redemocratização do perfil estatal quanto à organização do poder executivo através do acesso eleitoral dos partidos na esfera de governo. A reintrodução do acesso às instâncias de decisão através de eleições em todos os níveis, e a dinâmica de ocupação de cargos públicos pelos partidos, sobretudo a reintrodução do controle político na equipe ministerial, constituiu um campo importante para a produção de recursos de organização às agremiaçōes.

Desde o início do período, a esfera de governo, especificamente o poder executivo nacional, estabeleceu-se nas bases da aliança entre o PMDB e o PFL e tornou regular para todo o período uma dinâmica marcada por esta coalizão, retomando o padrão de governo desenvolvido no período democrático de 1945 a $1964 .{ }^{34}$

A análise deste padrão aponta dois aspectos. Em primeiro lugar, a presença constante da coalizão fundadora do regime democrático, PMDB-PFL, que sustenta todo o período. Desde já, o PFL começa a desenvolver seu forte perfil governista.

Em segundo lugar, a verificação de que a presença dos partidos no âmbito do poder executivo segue sobretudo uma orientação partidário-parlamentar, pela qual a coalizão governamental traduz o peso das organizaçōes

\footnotetext{
${ }^{34}$ Abranches, "Presidencialismo", 1988, vol. 31, núm. 1.
}

GOVERNO SARNEY: DILEMAS E VIRTUDES no Congresso, além dos compromissos políticos contraídos na transição.

O quadro 4 mostra a manutenção da coalizão PMDB-PFL em todas as reformas ministeriais do governo Sarney, e ilustra essa orientação reflexiva do Congresso no executivo. Os dados do quadro 4 apontam alguns aspectos importantes:

a) O peso da coalizão em cada equipe define uma maioria "justa" das cadeiras parlamentares, que versa, cm média, entre $54 \%$ e $56 \%$ da representação do Congresso Nacional. Este aspecto revela a presença de uma dinâmica de coalizões mínimas, pela qual o governo deteve o controle de uma maioria parlamentar por pequena margem, mesmo implementando um número considerável de alterações ministeriais que poderiam, teoricamente, ampliar o tamanho do apoio ao governo, mesmo que extrapolando a Aliança fundadora.

b) A composição de maior reflexo do Congresso ocorreu em 1987, logo após a realização das eleiçôes gerais de 1986. A representação da coalizão PMDBPFL no Congresso $-78 \%$ das cadeiras, sendo $77.6 \%$ na Câmara Federal e $83.2 \%$ no Senado- foi resultado direto do impacto do controle do PMDB sobre a condução do primeiro plano econômico o Plano Cruzado, quando nas eleições gerais de 1986 o número de cadeiras parlamentares do PMDB e do PFL aumentaram consideravelmente, além da vitória da Aliança em todos (23) os governos da federação.

Não há dúvida que a coalizão PMDBPFL no legislativo deu sustentação a todo período de governo, e traduziuse no apoio às ações da presidência, 
sobretudo à implementação das sucessivas reformas econômicas. Este apoio não limitou-se ao âmbito federal, pois a hegemonia da Aliança nos governos estaduais também constituiu níveis de cooperação com o governo federal. É sabido que em um federalismo forte como o brasileiro, os governadores exercem impacto sobre a organização do poder, através da formação de apoio e de influência sobre as bancadas parlamentares, de forma a atingir, inclusive, a dinâmica de formação das equipes ministeriais. Assim, no caso do governo Sarney, o domínio quase completo do PMDB nos governos a partir das eleições de 1986 (22 estados), apenas dividindo o controle com o PFL em um estado, conferiu ao governo federal total apoio das lideranças políticas estaduais.

Vejamos a presença dos partidos nas equipes ministeriais deste governo.

\section{A FORMAÇÃO DAS EQUIPES MINISTERIAIS}

A análise da dinâmica de distribuição dos ministérios durante os quatro anos do governo Sarney aponta para a centralidade dos partidos nos processos conduzidos na arena governamental.

São quatro as reformas ministeriais que caracterizam o governo Sarney, quais sejam, o período inicial de manutenção da equipe de Tancredo Neves; a reforma ministerial de fevereiro de 1986; as reformas de 1987, e a reforma de 1989. O ponto que se destaca em todos eles é a unidade da equipe, expressa na manutenção da coalizão PMDBPFL, que domina as bases partidárias do governo por todo o período, em todas as trocas de ministérios ocorridas.

Assim, o primeiro aspecto característico da composição desta equipe é seu caráter predominantemente partidário.

$O$ conjunto dos ministérios traduz quase integralmente a coalizão PMDBPFL, que ocupa 20 das 22 pastas titulares, através das quais o poder executivo foi organizado em 1985. Assim, o conjunto de ministérios é formado por 91\% de nomeações partidárias, com uma distribuição de treze cargos (59\%) destinados ao PMDB, sete (32\%) ao PFL e apenas dois (9\%) ocupados por nomes sem vinculação partidária.

Em segundo lugar, a manutenção da coalizáo PMDB-PFL por todo o período de governo. Este aspecto indica a preservação do pacto partidário de transição estabelecido pela Aliança Democrática, a capacidade de controle político das duas agremiações na condução das políticas governamentais e, ainda, a capacidade de absorção das demandas e conflitos dirigidos ao poder executivo pelas várias forças políticas, inclusive de caráter regional. Estes pontos definiram, em boa parte, o predomínio de nomeações de natureza partidária dentro do conjunto de alterações ministeriais deste período (86\% do total).

Em terceiro lugar, a dinâmica de alterações intra-partidárias. Essa dinâmica marcou a quase totalidade das mudanças ministeriais realizadas, traduzindo a força das agremiaçóes na composição da equipe de governo, e uma capacidade de absorção das demandas políticas regionais através das transferências entre regióes -e não entre partidos-das pastas. 
Este foi, de fato, um período no qual a questão política federativa teve papel singular, pois, como já foi mencionado, o total controle dos governos estaduais pela coalizão PMDB-PFI, obtido nas eleições de 1986, conformou um cenário no qual o padrão de relações entre os estados e a Uniāo pode ocorrer sem confrontos, nos limites da composição política do governo federal.

Dessa forma, o predomínio das alterações nas regiões sudeste e nordeste em todas as equipes do período, permite afirmar estarem ali os focos básicos das demandas partidárias regionais, sobretudo oriundos do PMDB. ${ }^{35}$

Finalmente, é importante destacar que a coalizão PMDB-PFL responde durante todo o período de governo à maioria das forças congressuais, sugerindo uma dinâmica circular de retroalimentação entre as arenas representativa e governamental.

Vejamos especificamente como esses aspectos se apresentaram em cada reforma ministerial ocorrida neste governo.

\section{O período inicial: \\ março/85-janeiro/86}

Como já foi apontado, o governo Sarney herdou as negociações fundadoras do novo regime realizadas por Tancredo Neves. A presença da coalizão PMDB-PFL na composição da equipe governamental reflete, de um lado, as

${ }^{35}$ Neste período a principal crise de convivência intra-partidária do PMDB culminou na criação do PSDB em 1988.

GOVERNO SARNEY: DILEMAS E VIRTUDES articulações para a transição democrática e, de outro, o peso da composição no Congresso e nos estados, necessário à sustentação política do primeiro governo da transição.

A composição do primeiro ministério da Nova República espelha a estreiteza das mudanças: a incorporação de Aureliano Chaves, ex-vice-presidente do último governo militar, no Ministério de Minas e Energia, e a escolha de Francisco Dornelles, ${ }^{36}$ ex-diretor da Receita Federal, também do últìmo governo militar, para o Ministério da Fazenda, são exemplos da manutenção dos antigos quadros políticos no novo regime.

Um segundo aspecto importante da organização introduzida por Tancredo ao poder executivo foi a definição de quatro novos ministérios, a saber, os ministérios da Administração, de Assuntos Fundiários, de Assuntos Extraordiários e da Desburocratização. Com esses novos ministérios, o novo regime dava corpo às questôes da reforma do Estado e da reforma agrária, preconizadas no documento fundador da Nova República.

Uma pequena nota sobre a questão agrária: não cabe deduzir que esta questão fora finalmente conduzida na direção de uma ampla reforma. A proposta elaborada pelo Ministério de Assuntos Fundiários em maio de 1985 -o Plano Nacional de Reforma Agrária- retomava os aspectos básicos presentes no Estatuto da Terra, lei aprovada pelo regime militar em 1964. Em

${ }^{36}$ Francisco Dornelles era também sobrinho de Tancredo Neves. 
todo o processo de elaboração do Plano, até a sua edição sob forma de decreto em outubro do mesmo ano, entidades patronais e militares, estes através do Conselho Nacional de Segu. rança, tiveram papel fundamental na alteração da proposta original do ministério, por sua vez mais progressista e detentora do apoio dos trabalhadores rurais e entidades vinculadas, inclusive o Movimento dos Trabalhadores Sem-Terra, existente desde 1981. A feição da questão agrária no período espelha a timidez das mudanças no novo regime.

Após um ano de governo, Sarney redimensionou seu governo, dando prioridade às medidas de estabilização monetária. Com isso, redefiniu a ocupação dos postos ligados à política econômica.

\section{A reforma de 1986}

A primeira alteração na equipe de governo foi marcada pela ampla reforma ministerial de fevereiro de 1986 , e resultou de um claro movimento conduzido pelo executivo na direção do maior domínio sobre a equipe de governo. $O$ importante a destacar é que este movimento não extrapolou os limites das bases partidárias originais de sustentação do regime.

Tais mudanças tiveram início com a substituição do ministro da Fazenda, em agosto de 1985, e pode ser compreendida como uma medida necessária para alterar a correlação de forças concorrentes entre o Ministério da Fazenda e a Presidência, bem como para redefinir o eixo central da política econômica originalmente estabelecida por Tancredo Neves.

A concentração dos órgãos de execução e controle da política econômica no Ministério da Fazenda desde o início do governo definiu este o ministério mais central para a condução das metas políticas, tornando-se portanto, fundamental para a construção das bases de liderança do presidente.

A substituição do ministro da Fazenda, Franciso Dornelles, um dos dois únicos membros da equipe sem vinculação partidária, por Dilson Funaro, empresário paulista, amigo pessoal do presidente Sarney e vinculado ao PMDB, apontava na direção da reforma ministerial do ano seguinte, através da qual Sarney desligou-se do cenário político herdado de Tancredo. Mais importante ainda, a substituição do ministro da Fazenda alterou a linha de condução de caráter conservador com um base monetarista, representada nas ações de Francisco Dornelles, para uma linha de condução de caráter populista, de base heterodoxa, e que teve expressão inicial no Plano Cruzado de fevereiro de $1986 .{ }^{37}$ Esta referência aos conteúdos diversos das políticas econômicas contribui para identificar o impacto da introdução do controle peemedebista sobre a pasta econômica.

A reforma de 1986 reorganizou o poder executivo extinguindo os quatro ministérios introduzidos por Tancredo, e alterou as ocupações de dez das 18 pastas, a saber, os ministérios da Justiça, Relações Exteriores, Agricultura, Transportes, Indústria e Comércio, Edu-

\footnotetext{
${ }^{37}$ Sallum Jr., "Por quê", 1988; Pereira, Economic, 1996.
} 


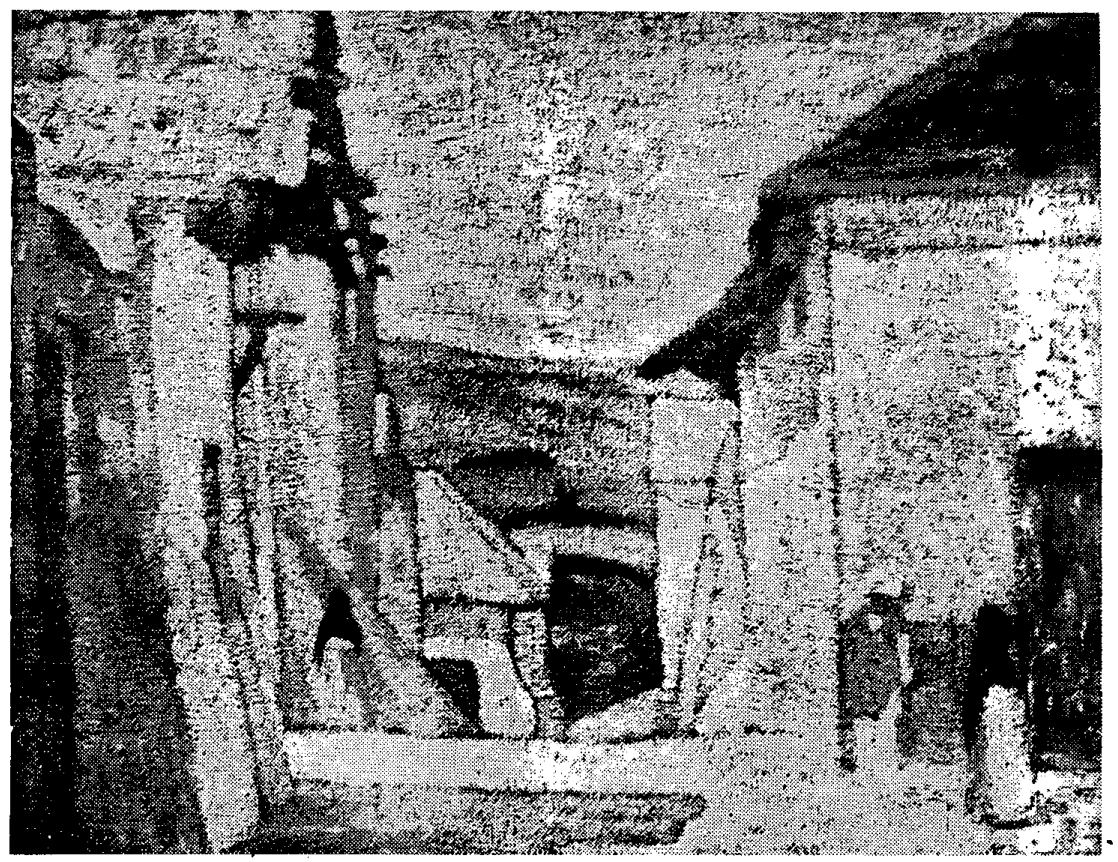

cação e Cultura, Saúde, Previdência, Cultura, Desenvolvimento Urbano (ver quadro 10).

Ainda em 1986, com a extinção do Ministério de Assuntos Fundiários, foi introduzido no organograma o MIRAD -Ministério da Reforma e Desenvolvimento Agrário (agosto/86). Como apontamos, contudo, a aprovação em outubro-daquele ano por decreto-lei do contestado Plano Nacional, dava os limites da mudança da questão agrária. Os conflitos nessa área levaram à extinção desta pasta no último ano de governo.

Com relação à correspondência com o legislativo, esta reforma ministerial ocorreu sob a base congressual do ano de 1985, também não alterando praticamente a correspondência com a representação da coalizão PMDB-PFL no Congresso, de por volta de $56 \%$ das cadeiras parlamentares (ver quadros 1 e 2).

Quanto à distribuição regional, no novo ministério Sarney as regiões sudeste e sul ganharam maior peso, embora a nova composição não tenha alterado o domínio global das regióes sudeste e nordeste, já presente na equipe anterior (ver quadro 5).

Com relação às áreas de atuação ministerial, as principais alterações ocor- 
ridas no organograma e na composição da equipe indicam uma atuação da Presidência no sentido de estabelecer um perfil político próprio para o governo, desvinculado da imagem constituída com Tancredo Neves. A redução dos ministérios da área política e a transferência da pasta da Fazenda para o PMDB convergem para a definição da política econômica -através do Plano Cruzado, anunciado logo em seguida à reforma- como o ponto de concentração do apoio político e de irradiação da legitimação do governo.

\section{As reformas de 1987}

O ano de 1987 abrigou várias alterações na equipe ministerial, mas três delas são destacadas como as de maior implicação na composição do governo: a alteração da equipe econômica realizada no mês de abril; a reforma de outubro, e a nova alteração da equipe econômica em dezembro.

Três aspectos caracterizaram tais alterações:

a) a manutenção das indicações partidárias dentro da coalizão PMDB-PFL;

b) a manutenção da quase totalidade das substituições partidárias dentro do partido da ocupação anterior da pasta (apenas um ministério foi deslocado do PMDB para o PFL);

c) a transformação das principais pastas ligadas à política econômica em pastas técnicas, com nomeações não-partidárias.

Em termos globais, as reformas de 1987 confirmam a unidade partidária da equipe de governo, quanto à alocação e ao controle das pastas. Para as pastas ligadas à política econômica, as alteraçôes ocorridas em abril e dezembro desse ano resultaram de intervenções do poder executivo e tiveram um impacto significativo na natureza da equipe de governo, alterando-a para uma nova composição de caráter técnico. As mudanças deram-se no Ministério da Fazenda e na Secretaria de Planejamento, órgãos centrais da política de estabilização conduzida por José Sarney, e refletiram de forma direta a ineficácia dos planos econômicos, inicialmente o Plano Cruzado, em seguida o Plano Cruzado II e, finalmente, o Plano Bresser.

Tais mudanças ocorreram em períodos diferentes, no início e no final do ano de 1987, cada uma delas como reação ao fracasso do controle político destes ministérios. Assim, no mês de março, ocorreu a substituição do ministro da Secretaria de Planejamento, executor do Plano Cruzado e ligado ao PMDB, João Sayad, por Aníbal Teixeira de Souza, uma nomeação de caráter técnico, que retirava da pasta a influência e o controle diretos do partido, mostrando uma estratégia clara da Presidência para recuperação do fortalecimento do poder executivo obtido durante o sucesso do Plano Cruzado.

Paralelamente, a substituição do ministro da Fazenda Dilson Funaro, ligado ao PMDB, por Luis Carlos Bresser Pereira, economista ligado ao mesmo partido, ocorreu devido à intervenção direta do partido na disputa com a Presidência da república para a manutenção desta pasta. ${ }^{38}$

${ }^{38} \mathrm{O}$ conflito entre José Sarney e Ulisses Guimaräes, presidente do $\mathrm{PMDB}$, desencadeado 
Após o desenvolvimento do Plano Bresser, outra experiência de choque heterodoxo também mal sucedida, o governo Sarney estabeleceu um perfil técnico definitivo às pastas diretamente ligadas à elaboração e condução da política econômica, nomeando em dezembro daquele ano para o cargo de ministro da Fazenda um técnico de carreira pública, Maílson da Nóbrega, e em seguida, em janeiro de 1988, João Batista de Abreu, nomeado para a pasta do Planejamento.

Em linhas gerais, essas nomeações caracterizaram a mudança do governo na condução da política de estabilização, antes dotada de forte componente político, para uma conduta convencional conhecida como política do "feijão com arroz". Um ano depois, com esta mesma equipe de ministros, o governo fez nova tentativa de impacto sobre a situação econômica, com a edição do Plano Verão.

As nomeações de caráter técnico e o consequente reperfilamento da condução da política econômica traduziram a relativa autonomia da Presidência da república na composição da equipe de governo e o controle sobre as áreas centrais de sustentação política.

Para as alterações nas demais pastas ministeriais, é fundamental observar que todas ocorrem dentro da coalizão partidária existente, sobretudo dentro do partido de origem. Contudo, a influência do aspecto regional modifica a composição política do conjunto, na qual se observa a existência de uma dinâmica de compensações e de busca

com a demissão de Dilson Funaro, está mencionado em Singer, "Intelectuais", 1988. de equilíbrio para a alocação de pastas entre regióes.

No início de 1988, após ter realizado alterações nas três áreas de atuação, o ministério Sarney manteve-se organizado em 19 pastas, distribuídas em $53 \%$ para o PMDB e $32 \%$ para o PFL, tal como apresentam o quadro 6.

\section{A reforma de 1989}

O último ano do governo Sarney realizou mudanças importantes na equipe ministerial que alteraram o número e a natureza das nomeaçốes efetuadas. Novamente, o destaque desta reforma é a definição das mudanças nos limites partidários da coalizão PMDB-PFL, confirmando a força da Aliança Democrática na composição e condução do primeiro governo.

Com a reforma de 1989 foram extintos três importantes ministérios da área social e política, houve a fusão de duas pastas da área econômica, e a equipe ministerial formada foi a de maior composição técnica de todo o período. Vejamos cada uma dessas modificações.

Foi apontado que o governo Sarney realizou em cada um dos anos de mandato alguma modificação na equipe ministerial. Ainda em 1988 três alterações foram efetuadas quanto ao organograma, através da extinção do Ministério de Habitação e Urbanismo e a criação do Ministério da Habitação e Bem-Estar Social, sem alterar a ocupação regional e partidária (PMDB/Nordeste); e quanto à ocupação de pastas, através da transferência do Ministério da Previdência e Assistência Social 
ocupado pelo PMDB da região sudeste para o PMDB da região norte, e a substituição dentre nomes do PMDB da região sudeste no Ministério da Cultura.

A reforma de 1989 teve maior im. pacto, e alterou o organograma ministerial através da extinção dos ministérios sociais da Irrigação e do Bem-Estar Social e do Ministério político da Reforma e Desenvolvimento Agrário; e através da transformação do Ministério econômico da Ciência e Tecnologia em Secretaria Especial, transferindo o status ministerial desta pasta para o Ministério da Indústria e Comércio.

Sobre o aspecto regional, esta reforma manteve a predominância da região sudeste sobre a região nordeste, as duas regiôes mais beneficiadas durante todo este governo.

Finalmente, sobre a natureza das nomeações, o perfil dos ministérios foi significativamente alterado através da definição de pastas de natureza técnica. A distribuição partidária e regional está no quadro 7.

Cabe ainda a referência à representação da coalizão partidária do governo no Congresso Nacional neste período. Com os trabalhos desenvolvidos pela Assembléia Constituinte iniciada em 1987, a composição de forças no Congresso em 1989 foi significativamente alterada: a formação do $\mathrm{PSDB}$ em 1988, a partir de uma cisão interna ao PMDB, modificou a força parlamentar original da Aliança Democrática diante do conjunto de partidos representativos, mas não alterou a sua predominância, mantendo mais da metade das cadeiras do Congresso (53.4\%).

Para todo o período pós-85, os ministérios da área econômica constituem para os partidos um locus prioritário de controle político. Para o governo Sarney, a distribuição dos ministérios nessa área expressa claramente essa prioridade e sugere, portanto, uma capacidade de influência dos partidos na definição das intervençôes sobre a política econômica e sua condução.

A composição ministerial das três áreas de atuação para todo o governo Sarney apresenta algumas importantes características. A presença da coalizão PMDB-PFL no conjunto de pastas ministeriais indica a sua capacidade de adequação ao projeto de reformas definido pela Aliança Democrática e a determinação do governo na manutenção desse perfil, mesmo com as crises ocorridas no período. A unidade partidária da equipe de governo traduz um requisito básico para a implementação das medidas acordadas.

Para cada uma das áreas de atuação ministerial predominam de forma destacada as ocupaçóes de caráter partidário: para a área econômica, $75 \%$ deram-se dentro da coalizão partidária, e $25 \%$ se caracterizaram sem vínculos com partidos; para a área social, 95\% ocorreram dentro da coalizão PMDBPFL, com apenas uma nomeação sem vínculo partidário; para a área política, 87\% foram de caráter partidário.

A manutenção das várias substituições ministeriais no mesmo partido -PMDB- aponta para dois fatores explicativos do domínio partidário: inicialmente, indica a presença de estruturas e quadros especializados para a elaboração e implementação de políticas. Em segundo lugar, indica que o controle partidário dos ministérios responde a fatores regionais e, no caso, 
traduzia a predominância da região sudeste (os ministérios da Fazenda, Planejamento, Indústria e Comércio, e Trabalho; e de atuação social: o Ministério da Cultura).

Dentro do PFL, destaca-se o controle do nordeste nas pastas econômicas de Irrigação e Interior, e na área social, os ministérios das Comunicações e da Educação. Para a região sudeste, apenas destaca-se a pasta política das Relações Exteriores.

As dificuldades observadas para a implementação dos planos de estabilização em momentos específicos sugerem a concorrência entre a influência partidária e a autonomia da Presidência na dinâmica de elaboração e implementação das medidas. Sob esse prisma pode ser observada a substituição de Francisco Dornelles por uma indicação claramente partidária no Ministério da Fazenda, logo no início do governo. Da mesma forma, a alteração do perfil partidário da equipe econômica para um perfil técnico, no período crítico de 1989, é uma indicação significativa do controle partidário que competia, nesse caso, com a Presidência da república na busca de recuperação $e$ sustentação políticas. Neste sentido, o uso exacerbado do recurso constitucional da "medida provisória" como um instrumento para agilizar a implementação de medidas para o controle inflacionário no período final do governo refletiu o enfraquecimento dessa relação entre poderes.

$O$ importante a apontar na presença de uma dinâmica de coalizão na organização e funcionamento do executivo deste primeiro governo é que essa lógica constiutiu um fator indis- sociável da capacidade de governo, e sublinhou a importância dos partidos, através da necessidade de base parlamentar para se sustentar.

Este é um dado também importante porque diz respeito ao funcionamento do presidencialismo e a interação entre o sistema de governo e o sistema partidário: este estudo das relações entre os poderes executivo e legislativo revela que a autonomia da Presidência da república encontrou limites importantes na força dos partidos no Congresso.

Esses fatores apontam para a questão da governabilidade neste período.

\section{A BUSCA DE GOVERNABILIDADE: o IMPACTO DOS PLANOS ECONÓMICOS SOBRE A ESTABILIDADE DO GOVERNO}

Embora este primeiro governo democrático indicasse limitaçōes no funcionamento do presidencialismo brasileiro, advindas da relação com os partidos, o grau de governabilidade esteve diretamente dimensionado pela capacidade de implementação das políticas públicas pelo executivo.

Mais ainda, a credibilidade na condução política e a popularidade com relação às reformas preconizadas definiram-se no campo das ações redistributivas de mais amplo impacto social, estabelecendo as reformas econômicas como o elemento central da estabilidade inicial. A governabilidade adquiriu, como significado, a soberania do executivo sobre a moeda.

Os estudos sobre a experiência da política econômica brasileira apontam o poder executivo como o fórum do- 
minante das negociações e da representação de interesses, no qual o sistema de decisóes incorporou os padróes de interação entre técnicos e políticos introduzidos pelo realinhamento democrático em 1985 . $^{39}$

A reforma econômica e os planos de estabilização constituiram-se os itens centrais do resgate imediato da condição social, tratado pelo governo como recuperação do poder de compra dos salários e redução do desemprego. Especificamente com o Plano Cruzado, a possibilidade de redução do desemprego contou com amplas expectativas positivas da população. Em survey realizado em cinco capitais estaduais, $38 \%$ dos entrevistados afirmaram acreditar que o desemprego iria diminuir. Essa opinião se manteria mesmo após o descongelamento em dezembro. ${ }^{40}$

O Plano Cruzado conseguiu índices de mobilização consideráveis da população em torno do sucesso das medidas, e estimulou o surgimento de uma figura que se tornou símbolo do governo -o "fiscal do Sarney": o brasileiro que apoiava o plano, participava da fiscalização dos preços e denunciava os abusos econômicos, produzindo grande visibilidade para os resultados obtidos. Em survey realizado um mês após a edição do plano, $50 \%$ da popülação de seis capitais estaduais afirmavam participar da fiscalização já na primeira semana de vigência, e $39 \%$ afirmavam-se dispostos a participar.

39 Sola, "Choque", 1988; Singer, "Intelectuais", 1988; Pereira, Economic, 1996.

${ }^{40}$ Encarte, Opiniāo Pública, 1994.
Mesmo com o descongelamento de preços em dezembro de 1986 e a sucessão de planos fracassados, o grau de mobilização popular frente às ações econômicas do governo federal era positivo. As pesquisas mostraram que não menos de $30 \%$ da população dos grandes centros se mantinham dispostos a fiscalizar e participar diretamente da implementação das medidas. ${ }^{41}$

No entanto, a bibliografia que analisa o desenvolvimento da política econômica deste governo aponta como componentes potenciais da instabilidade do governo Sarney os constrangimentos que conduziram ao fracasso do Plano Cruzado, à sucessão de medidas econômicas e à definição do Plano Cruzado II logo após as eleiçôes gerais de 1986, e na deterioração da situação econômica interna. ${ }^{42}$ Como vimos, esta situação estabeleceu, de fato, o principal fator para a alteração da equipe éconômica traduzida na reforma ministerial de 1987.

Não foi curta a sucessão de planos do período, afirmando a estabilização da moeda como o pilar da alta popularidade presidencial que somente seria repetido no governo Fernando Henrique em 1994, com o Plano Real. Assim, o conjunto de planos deste governo teve início com o Plano Cruzado, vigente entre março e dezembro de 1986 , um plano heterodoxo baseado no congelamento de preços. Com a inflação caída a zero, foi enorme o apoio popular recebido. Em dezembro do mesmo ano, após as eleições que deram vi-

\footnotetext{
${ }^{41}$ Ibid.

${ }^{42}$ Moura, "Rumo", 1990; Sola, "Choque", 1988.
} 
tória esmagadora ao partido do governo, tornou-se impossível manter os preços congelados e a inflação explodiu novamente, com a edição do Plano Cruzado II.

É importante apontar a força da coalizão PMDB-PFL diante da instabilidade instalada com o fracasso do plano. Esta foi a condição necessária para que, mesmo frente à crise estabelecida, as modificações feitas na equipe de governo ocorressem todas nos limites da coalizão. Assim, em junho de 1987, com um nova equipe econômica ministerial com bases no PMDB, foi lançado o Plano Bresser, um plano de emergência baseado em congelamento de preços de curto prazo e no ajuste fiscal. Vigente até dezembro daquele ano, não conseguiu sucesso devido à falta de apoio político, e pôs termo à administração partidária peemedebista da política econômica.

Buscando contornar a incapacidade política governamental, a Presidência redimensionou tecnicamente a política econômica, e após alterar o ministério em 1988, lançou o Plano Feijão com Arroz, ${ }^{43}$ um programa ortodoxo de bases convencionais, voltado para a adoção de uma política fiscal e monetária. Igualmente foi ineficiente como plano de estabilização e não conseguiu obter apoio político para o ajuste fiscal, levando a que a inflação em fins de daquele ano chegasse a $30 \%$ ao mês.

Finalmente, já no último ano de seu mandato, Sarney editou em janeiro de

\footnotetext{
${ }^{43}$ Esta é una alusāo feita a um dos pratos mais convencionais da cozinha brasileira.
}

1989 o Plano Verão, uma combinação de condução heterodoxa (congelamento de preços, desindexação e reforma monetária) e ortodoxa monetarista. Ao final desse período, o mandato de Sarney terminava com os mais baixos índices de popularidade de qualquer presidente da Nova República.

Por volta de dezembro, época da primeira eleição presidencial direta, a taxa de inflação estava em torno de $50 \%$ ao mês, conformando um cenário apropriado para o crescimento do apoio à candidatura populista de Fernando Collor de Mello, o presidente do seguinte período, eleito pelo voto direto.

\section{AVANÇOS E RETROCESSOS}

Não há dúvida em afirmar que o período inicial de um regime democrático transitado de forma negociada, pelo "alto", abriga resquícios das práticas políticas comprometidas com a situação autoritária anterior.

Em que pesem as alteraçóes institucionais e a definição de procedimentos democráticos, a ambigüidade dos papéis dos atores do velho regime promoveu cenários durante o governo Sarney nos quais sinais de retrocesso não faltaram.

Além das evidências de continuidade dos velhos personagens e da timidez das mudanças preconizadas, 0 final de governo abrigou distintos processos políticos, ideologicamente polarizados, contornados por uma crise inflacionária que refletia o alto grau de ingovernabilidade. A título de exemplo, em fins de 1988, ocuparam o mesmo espaço público a invasão pelo Exér- 


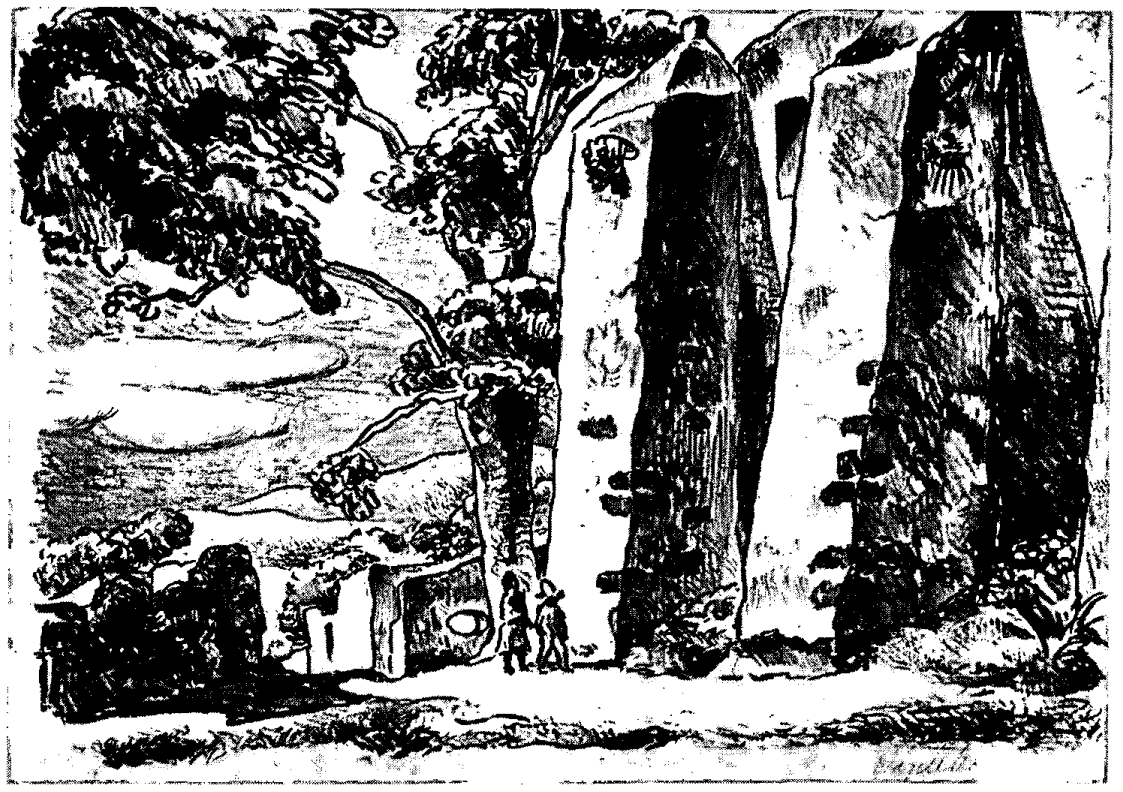

cito da Companhia Siderúrgica Nacional então ocupada por grevistas, e a vitória da esquerda em várias grandes cidades nas eleições municipais de novembro; em 1989, a extinção do Ministério da Reforma Agrária, e a realização das primeiras eleiçôes diretas para presidente após 29 anos.

O que se verá no período posterior, no entanto, é a manutenção de um padrão de funcionamento combinado entre os poderes legislativo e executivo e uma dinâmica regular de participação dos partidos na organização do governo federal, mostrando que os patamares de governabilidade adquirida ao longo do período são relação direta da associação entre partidos e governos democráticos.

Nossa experiência democrática ainda é recente para permitir afirmações sobre o desenvolvimento partidário. As observações aqui apresentadas, no entanto, revelam que a centralidade readquirida pelos partidos nos processos políticos ainda iniciais do período já indicavam passos importantes no sentido da sua consolidação.

E-mail: racael@turing.unicamp.br 
Quadro 1. Composição da Câmara de Deputados Brasil (1984-1989) (n)

\begin{tabular}{|c|c|c|c|c|c|}
\hline & & 1984 & 1985 & $1987^{a}$ & 198 \\
\hline \multirow[t]{5}{*}{ Esquerda } & PT & 8 & 8 & 16 & 16 \\
\hline & PDT & 23 & 23 & 24 & 31 \\
\hline & PCB/PPS & & & 3 & 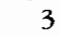 \\
\hline & PTcdo B & & & 3 & 6 \\
\hline & PSB & & & 1 & 7 \\
\hline \multirow[t]{2}{*}{ Centro } & PMDB & 200 & 201 & 260 & 175 \\
\hline & PMDB & & & & 51 \\
\hline \multirow[t]{7}{*}{ Direita } & PFL & & 70 & 118 & 89 \\
\hline & PTB & 13 & 12 & 17 & 21 \\
\hline & PCB/PPB & 235 & 165 & 33 & 32 \\
\hline & PDC & & & 5 & 14 \\
\hline & PL & & & 6 & 16 \\
\hline & PRN & & & & 21 \\
\hline & PP & & & & \\
\hline Outros & & & 1 & 1 & 13 \\
\hline Total & & 479 & 479 & 487 & 495 \\
\hline
\end{tabular}

a Resultados da eleição realizada no ano anterior.

Fonte: Tribunal Superior Eleitoral (TSE), e Fleischer, "Sistema", 1997, p. 254.

Quadro 2. Composição do Senado Federal Brasil (1984-1989) (n)

\begin{tabular}{|c|c|c|c|c|c|}
\hline & & 1984 & 1985 & $1987^{a}$ & 1989 \\
\hline \multirow[t]{5}{*}{ Esquerda } & PT & 1 & & & \\
\hline & PDT & 1 & 1 & 2 & 3 \\
\hline & $\mathrm{PCB} / \mathrm{PPS}$ & & & & \\
\hline & PCdoB & & & & \\
\hline & PSB & & & 2 & 2 \\
\hline \multirow[t]{2}{*}{ Centro } & PMDB & 22 & 23 & 44 & 31 \\
\hline & PSDM & & & & 10 \\
\hline \multirow[t]{7}{*}{ Direita } & PFL & & 12 & 16 & 13 \\
\hline & PTB & & 1 & 1 & 4 \\
\hline & PCS/PPR & 45 & 31 & 5 & 2 \\
\hline & PDC & & & 1 & 4 \\
\hline & $\mathrm{PL}$ & & & 1 & 1 \\
\hline & PRN & & & & 2 \\
\hline & PP & & & & \\
\hline Outros & & & 2 & & 3 \\
\hline Total & & 69 & 69 & 72 & 75 \\
\hline
\end{tabular}

Fonte: TSE, e Fleischer, "Sistema", 1997, p. 254. 
Quadro 3. Partidos na Câmara Federal com representação igual ou maior a $5 \%$ das cadeiras 1985-1989 (\%)

1985

$1986^{a}$ 1989

\section{Esquerda}

PT

PDT

$5.0 \quad(24)$

6.3 (31)

Centro

PMDB

42.0 (201)

$52.9(257)$

35.4 (175)

PDSB

$10.3 \quad(51)$

1985

$1986^{a}$

1989

Direita

PFL

$14.6(70) \quad 24.2(118)$

$18.0 \quad(89)$

PTB

PDS/PPR

28.2 (135)

$6.8 \quad(33)$

$6.5 \quad(32)$

PRN

PP

${ }^{a}$ Resultados das eleiçóes gerais.

Fonte: Tribunal Superior Eleitoral (TSE).

Quadro 4. Coalizões partidárias no governo federal e representação no Congresso Nacional (1985-1989)

$\begin{array}{llccc}\text { Equipes } & \text { Partidos da } & C F & \text { Senado } & C N \\ \text { de governo } & \text { coalizäo }(n) & \% & \% & \%\end{array}$

Tancredo Neves

1985

PMDB-PFL

56.6

50.4

55.9

José Sarney

1986

PMDB-PFL

56.6

50.4

55.9

1987

PMDB-PFL

77.6

83.2

78.4

1989

PMDB-PFL

53.4

58.6

54.0

Fonte: TSE, e Quadros Ministeriais. 
Quadro 5. Distribuição regional e partidária do ministério Sarney, após a reforma de feb. de 1986 (\%)

$\begin{array}{lcccccc} & \text { Norte } & \text { Nordeste } & \text { Sul } & \text { Sudeste } & \begin{array}{c}\text { Centro- } \\ \text { Oeste }\end{array} & \text { Total } \\ \text { PMDB } & 1(5) & 2(11) & 2(11) & 7(37) & 1(5) & 13(68.4) \\ \text { PFL } & 2(11) & 1(5) & 2(11) & & 5(26.3) \\ \begin{array}{l}\text { S/partido } \\ \begin{array}{l}\text { Total de ocupações } \\ \text { partidárias }\end{array}\end{array} & 1(5) & & & & 1(5.3) \\ \begin{array}{l}\text { Total } \\ \text { natal }\end{array} & 1(5) & 5(27) & 3(16) & 9(48) & 1(5) & 19\end{array}$

Fonte: Quadro 10.

Quadro 6. Distribuição partidária e regional do ministério Sarney, após as reformas de 1987 (\%)

$\begin{array}{lcccccc} & \text { Norte } & \text { Nordeste } & \text { Sul } & \text { Sudeste } & \begin{array}{c}\text { Centro- } \\ \text { Oeste }\end{array} & \text { Total } \\ \text { PMDB } & 1(6) & 2(11) & 3(17) & 3(17) & 1(6) & 10(52.6) \\ \text { PFL } & & 3(17) & & 2(11) & & 6(31.6) \\ \begin{array}{l}\text { S/partido } \\ \text { Total das ocupaçóes } \\ \begin{array}{l}\text { partidárias } \\ \text { Total }\end{array}\end{array} & 1(6) & & 2(11) & & 3(15.8) \\ & 1(6) & 6(34) & 3(17) & 7(39) & 1(6) & 19(84.2)\end{array}$

Fonte: Quadro 10.

Quadro 7. Distribuição partidária e regional do ministério Sarney, após a reforma de 1989 (\%)

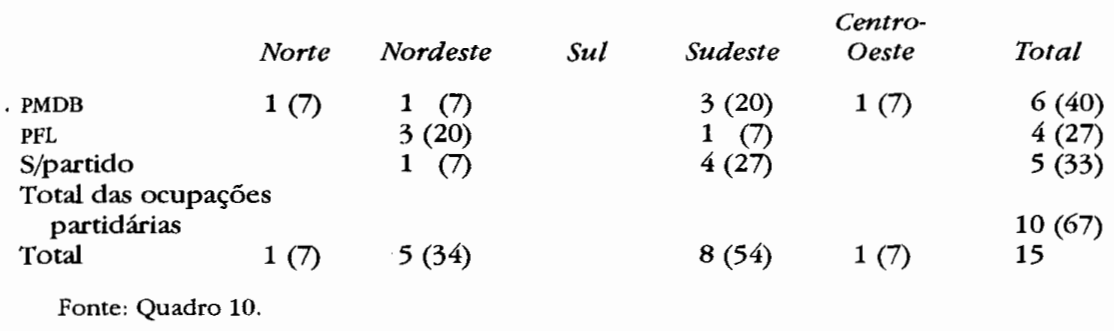


Quadro 8. Distribuição partidária e regional do ministério Sarney para todo o período de governo (1985-1989) (\%)

\begin{tabular}{|c|c|c|c|c|c|c|}
\hline & Norte & Nordeste & Sul & Sudeste & $\begin{array}{l}\text { Centro- } \\
\text { Oeste }\end{array}$ & Total \\
\hline PMDB & $4(6)$ & $12(19)$ & $5(8)$ & $16(25)$ & $3(5)$ & $41(65)$ \\
\hline PFL & & $8(13)$ & 1 (2) & $4(6)$ & & $13(21)$ \\
\hline S/partido & & 1 (2) & & $8(13)$ & & $9(14)$ \\
\hline $\begin{array}{l}\text { Total das ocupaçõe } \\
\text { partidárias }\end{array}$ & & & & & & $54(86)$ \\
\hline Total & $4(6)$ & $21(33)$ & $6(10)$ & $28(44)$ & $3(5)$ & 63 \\
\hline
\end{tabular}

Quadro 9. Equipe de ministros titulares. Equipe de Tancredo Neves (data de posse: março 15, 1985)

\section{Ministério}

Área econômica

Agricultura

Ciência e Teconologia

Fazenda

Indústria e Comércio

Interior

Irrigação

Minas e Energia

Planejamento

Transportes

Área social

Comunicaçōes

Cultura

Desenvolvimento Urbano,

Habitação e Meio Ambiente

Educação

Previdência Social

Saúde

Trabalho

Área política

Administração

Assuntos Extraordinários

Assuntos Fundiários

Desburocratização

Justiça

Relações Exteriores
Pedro Jorge Simon

Renato Archer

Francisco Neves Dornelles

Roberto Herbster Gusmão

Ronaldo Costa Couto

Vicente Cavalcante Fialho

Aureliano Chaves de Mendonça

João Sayad

Affonso Alves de Camargo Neto

Antonio Carlos Magalhães

José Aparecido de Oliveira

Flávio R. Peixoto da Silveira

Marco Antonio de O. Maciel

Francisco Waldir Pires de Souza

Carlos C. de Menezes Sant'anna

Almir Pazzianotto Pinto
Partido

Estado/ região

$\begin{array}{ll}\text { PMDB } & \text { RS/S } \\ \text { PMDB } & \text { MA/NE } \\ & \text { RJ/SE } \\ \text { PFL } & \text { SP/SE } \\ \text { PMDB } & \text { MG/SE } \\ \text { PFL } & \text { SE/NE } \\ \text { PFL } & \text { MG/SE } \\ \text { PMDB } & \text { SP/SE } \\ \text { PMDB } & \text { PR/S }\end{array}$

$\begin{array}{ll}\text { PFL } & \text { BA/NE } \\ \text { PMDB } & \text { MG/SE } \\ & \\ \text { PMDB } & \text { GO/CO } \\ \text { PFL } & \text { CE/NE } \\ \text { PMDB } & \text { BA/NE } \\ \text { PMDB } & \text { BN/NE } \\ \text { PMDB } & \text { SP/SE }\end{array}$

$\begin{array}{lll}\text { Aluísio Alves } & \text { PMDB } & \text { RN/NE } \\ \text { Mauro Salles } & & \text { SP/SE } \\ \text { Nelson de Figueiredo Ribciro } & \text { PMDB } & \text { PA/N } \\ \text { Paulo de Tarso Lustosa da Costa } & \text { PFL } & \text { CE/NE } \\ \text { Fernando Soares iyra } & \text { PMDB } & \text { PE/NE } \\ \text { Olavo Egydio Setúbal } & \text { PFL } & \text { SP/SE }\end{array}$

Fonte: Dept. de Documentação, Divisão de Informação-Presidência da República, Brasília. 


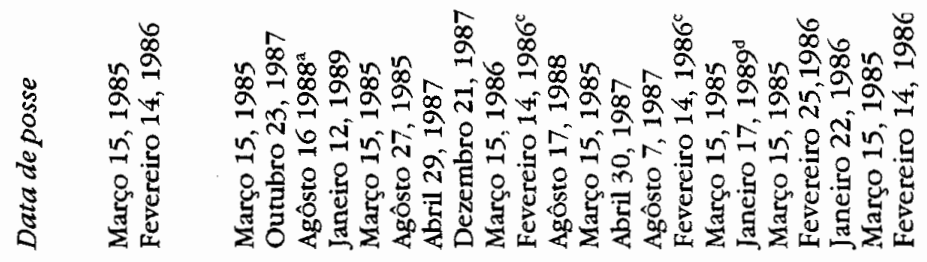

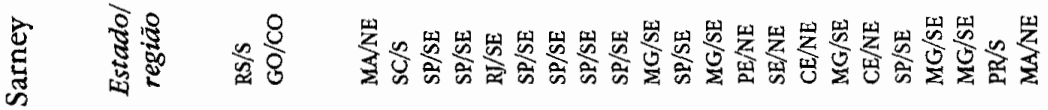

品

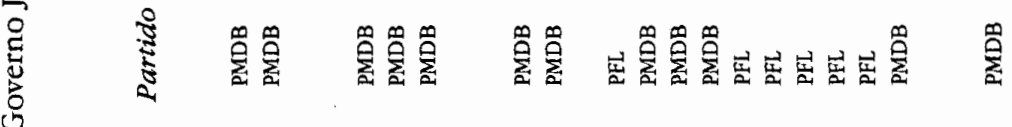
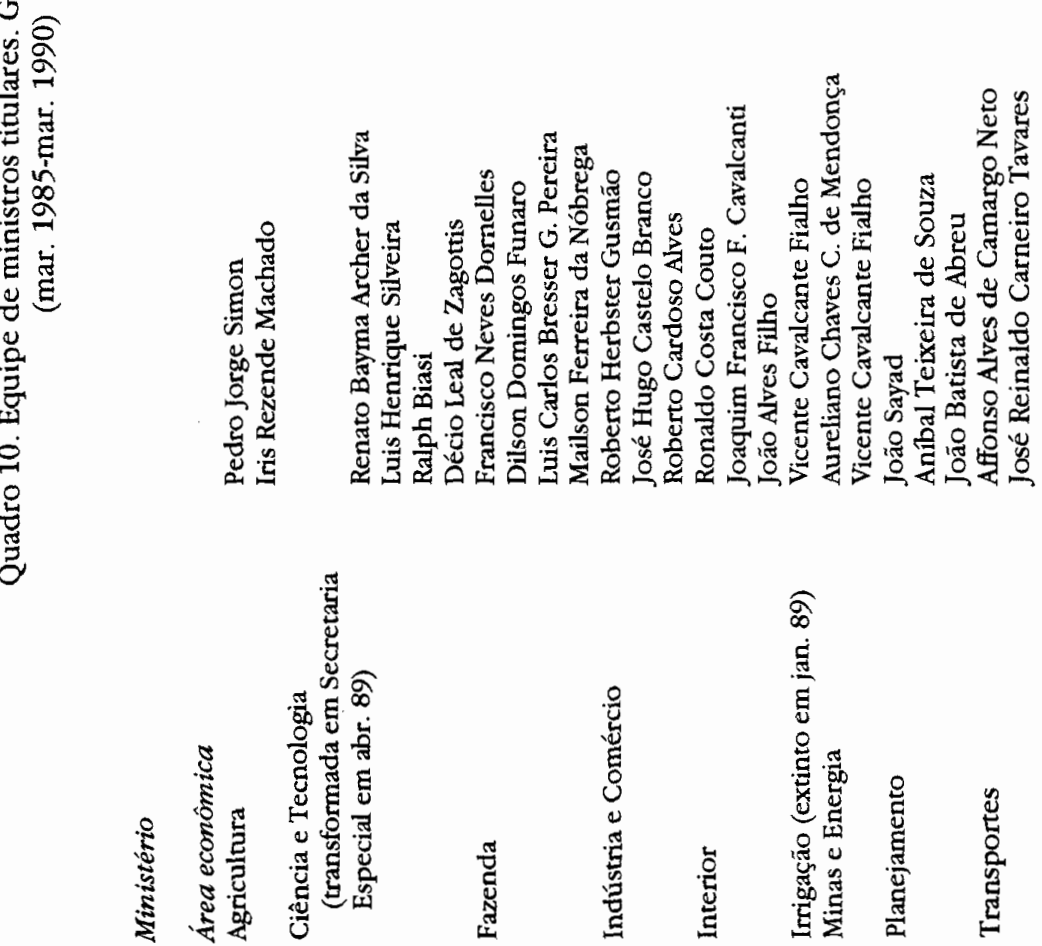


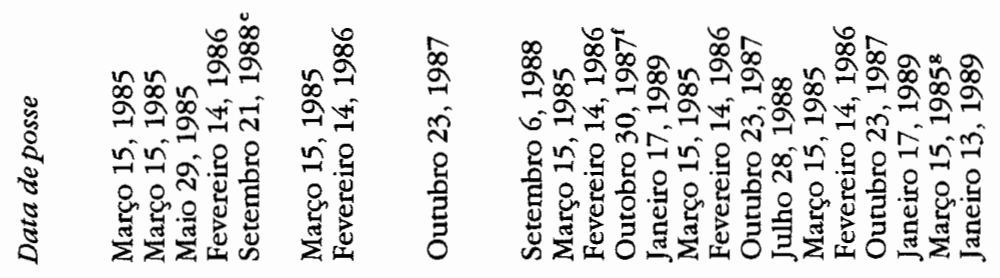

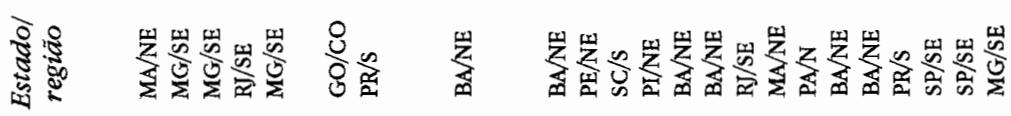

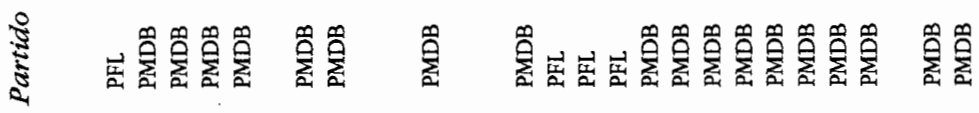

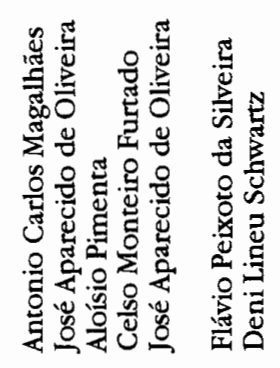

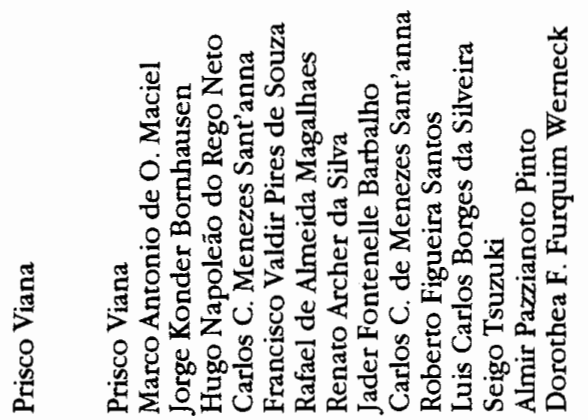

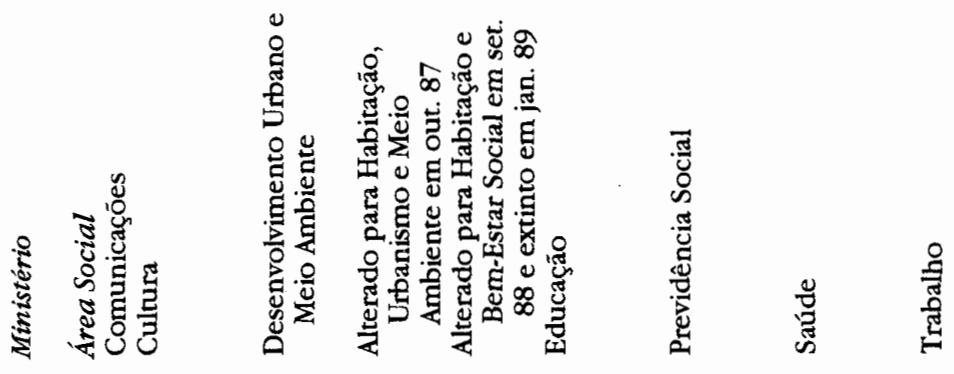




\section{SECUENCIG}

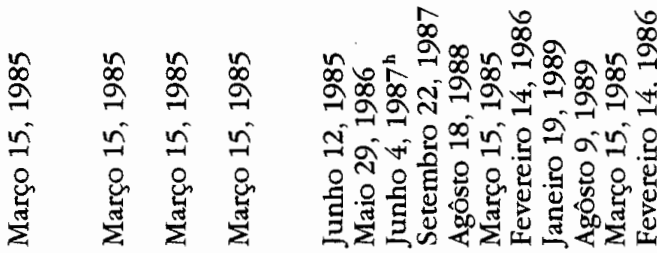

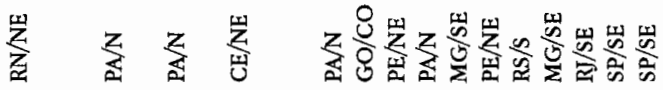

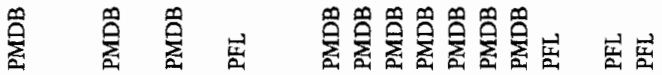

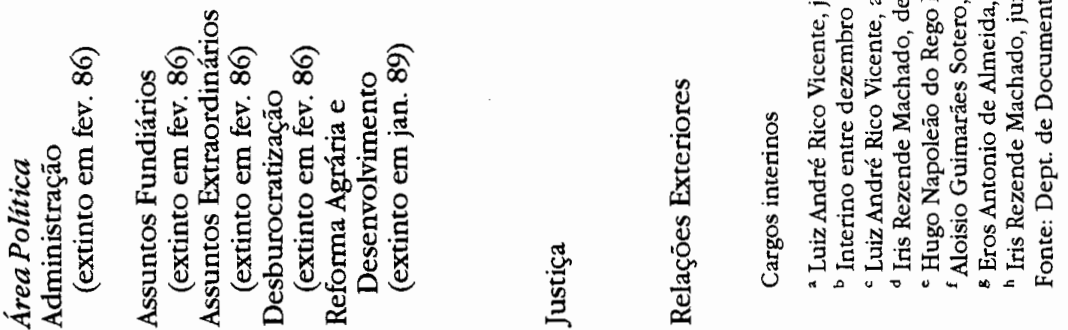




\section{BIBLIOGRAFIA}

-Abranches, Sérgio, "Presidencialismo de coalizão", Revista Dados, vol. 31, núm. 1, 1988, Rio de Janeiro.

-Anuário Estatístico, IBGE, 1992, Rio de Janeiro.

-Baldasarre, Antonio, "L'evoluzione dei partiti politici" in Joachim Raschke (org.), I partiti dell'Europa Occidentale, Ed. Riuniti, Roma, 1983

-Budge, Ian e Hans Keman, Parties and democracy. Coalition formation and government functioning in twenty States, Oxford UP, Oxford, 1990.

-Camargo, Aspásia e Eli Diniz (orgs.), Continuidade e mudança no Brasil da Nova República, Vértice/Iuperj, Rio de Janeiro, 1989.

Constituição da República Federativa do Brasil, 1967.

Constituição da República Federativa do Brasil, 1988.

-DIAP-Depart. Intersindical de Assessoria Parlamentar, Quem foi quem na Constituinte, Cortez/Oboré, São Paulo, 1988.

-Diniz, Eli, "Governabilidade, democracia e reforma do Estado, os desafios da costrução de uma nova ordem no Brasil dos anos 90", Revista Dados, vol. 38, núm. 31995.

-Dreifuss, René, "Nova República. Novo Exército?" in Flávio Koutzii (org.), Nova República, um balanço, L\&PM Ed., São Paulo, 1986.

-Encarte de dados núm. 3, "Brasil, planos econômicos", Revista Opinião Públi$c a$, CESOP-Unicamp, ano II, vol. II, núm. 1, 1994, Campinas.

-Evers, Tilman, "De costas para o Estado, longe do Parlamento", SP, Novos Estudos Cebrap, vol. 2, núm. 1, 1983.

-Farneti, Paolo, "Partiti, Stato e mercato, appunti per un'analisi comparata" in Paolo Farneti, I sistemi di partito, Franco Angeli, Milano, 1986.

-Figueiredo, Argelina e Fernando Limongi, "Terra incógnita, funcionamento e perspectivas do Congresso Nacional", Relatório de Pesquisa, CEBRAP, São, Paulo, 1995.

-Figueiredo, Argelina e Fernando Limongi, "Mudança constitucional e desempenho legislativo", Revista Brasileira de Ciências Sociais, núm. 29, ounubro, 1995, São Paulo.

-Fleischer, David, "Sistema partidário brasileiro", Política Comparada, Ed. Arko Advice, vol. 1, núm. 2, 1997, Brasília.

-Ginsberg, Benjamin, The captive public -bow mass opinion promotes State power, Basic Books, New York, 1986.

-Harmel, Robert e John D. Robertson, "Formation and success of new parties, a cross-national analysis", International Science Political Review, vol. 6, núm. 4, 1985, pp. 501-523.

-Katz, Richard e Peter Mair (eds.), How parties organize. Change and adaptation in party organizations in western democracies, Sage Publications, London, 1994.

-Kinzo, Maria D., Radiografia do quadro partidário, Fundação Konrad-Adenauer, São Paulo, 1993.

, "O quadro partidário e a Constituinte" in Bolivar Lamounier (org.), De Geisel a Collor, o balanço da transição, Idesp/Sumaré, São Paulo, 1990.

-Klingemann, Hans-Dieter, Richard Hofferbert e Ian Budge, Parties, policies and democracy, Westview Press, 1994.

-Lamounier, Bolivar, "Apontamentos sobre a questão democrática brasileira" in Rouquié, Schvarzer e Lamounier (orgs.), Como renascem as democracias, Brasiliense, São Paulo, 1985.

"Opening through elec tions, will the brazilian case become a paradigm?", Government and Opposition, vol. 19, núm. 2, 1984.

-Lawson, Kay e Peter Merkl (eds.), When parties fail. Emerging alternative organizations, Princeton UP, Princeton, 1988.

-Lawson, Kay, "When linkage fails" in Kay Lawson e Peter Merkl, (eds.), When parties fail. Emerging alternative organi- 
zations, Princeton UP, Princeton, 1988, pp.13-38.

-Malloy, James, "Política econômica e o problema da governabilidade nos Andes centrais" in Lourdes Sola (org.), Estado, mercado e democracia, política e economia comparada, Paz e Terra, São Paulo, 1993.

-Manin, Bernard, "As metamorfoses do governo representativo", Revista Brasileira de Ciências Sociais, núm. 29, 1995.

-Meneguello, Rachel, "Mudanças e continuidades na transição democrática brasileira" in Huellas de las transiciones politicas. Partidos y elecciones en América Latina, Instituto Mora, México, 1998.

-Moura, Alkimar, "Rumo à entropia, a política econômica, de Geisel a Collor" in Bolivar Lamounier, De Geisel a Collor, um balanço da transição, Ed. Sumaré, São Paulo, 1990.

-Pennock, Roland, Democratic political theory, Princeton UP, Princeton, 1979.

-Pereira, Luiz Carlos Bresser, Economic crisis \& State reform in Brazil. Toward a new interpretation of Latin America, Lynne Rienner, New York, 1996.

-Pizzorno, Alessandro, "Interests and parties in pluralism" in S. Berger (org.), Organizing interests in western Europe -pluralism, corporatism and the transformation of politics, Sage, London, 1981.

-Rodrigues, Leôncio Martins, Quem é quem na Constituinte -uma análise sócio-politica dos partidos e deputados, OESP-Maltese, São Paulo, 1987.

-Sallum Jr., Brasílio, "Por quê não tem dado certo, notas sobre a transição política brasileira" in Lourdes Sola (org.), O Estado da transiçăo, política e economia na Nova República, Vértice, São Paulo, 1988.

-Sallum Jr., Brasílio, Eduardo Graeff e Carlos Estevam Martins, "Nova República, de Tancredo a Sarney", Análise Conjuntural, IPARDES, vol. 8, núm. 2, 1986, Curitiba.
-Sartori, Giovanni, Partidos e sistemas partidários, Zahar/UnB, Rio de Janeiro e Brasília, 1982.

-Shefter, Martin, Political parties and the State.The american bistorical experience, Princeton UP, Princeton, 1994.

-Singer, Paul, "Intelectuais de esquerda no Brasil, a experiência do poder" in Lourdes Sola (org.), O Estado da transição, política e economia na Nova República, Vértice, São Paulo, 1988.

-Sola, Lourdes, "Choque heterodoxo e transição democrática sem ruptura, uma abordagem transdisciplinar" in Lourdes Sola (org.), O Estado da transiçäo, política e economia na Nova República, Vértice, São Paulo, 1988.

-Souza, Maria do Carmo Campello de, "Sob a espada de Dâmocles, a Nova República brasileira" in Alfred Stepan (org.), Democratizando o Brasil, Paz e Terra, São Paulo, 1989.

-Torre, Juan Carlos, "América Latina, el gobierno de la democracia en tiempos difíciles", Documentos, Instituto de Estudos Avançados-USP, São Paulo, 1991.

-Torres-Rivas, Edelberto, "Democracy and the metaphor of good government" in Joseph Tulchin (ed.), The consolidation of democracy in Latin America, Lynne Rienner Pub, New York, 1995.

-Velasco e Cruz, Sebastião, "De Castello a Figueiredo. Uma incursão na pré-história da abertura" in Almeida \& Sorj (orgs.), Sociedade e política no Brasil pós-64, Brasiliense, São Paulo, 1983.

-Wilson, Frank, "When parties refuse to fail, the case of France" in Kay Lawson e Peter Merkl (eds.), When parties fail. Emerging alternative organizations, Princeton UP, Princeton, 1988.

-World Bank, Governance and development, Washington, 1992. 


\section{SECUENCIA}

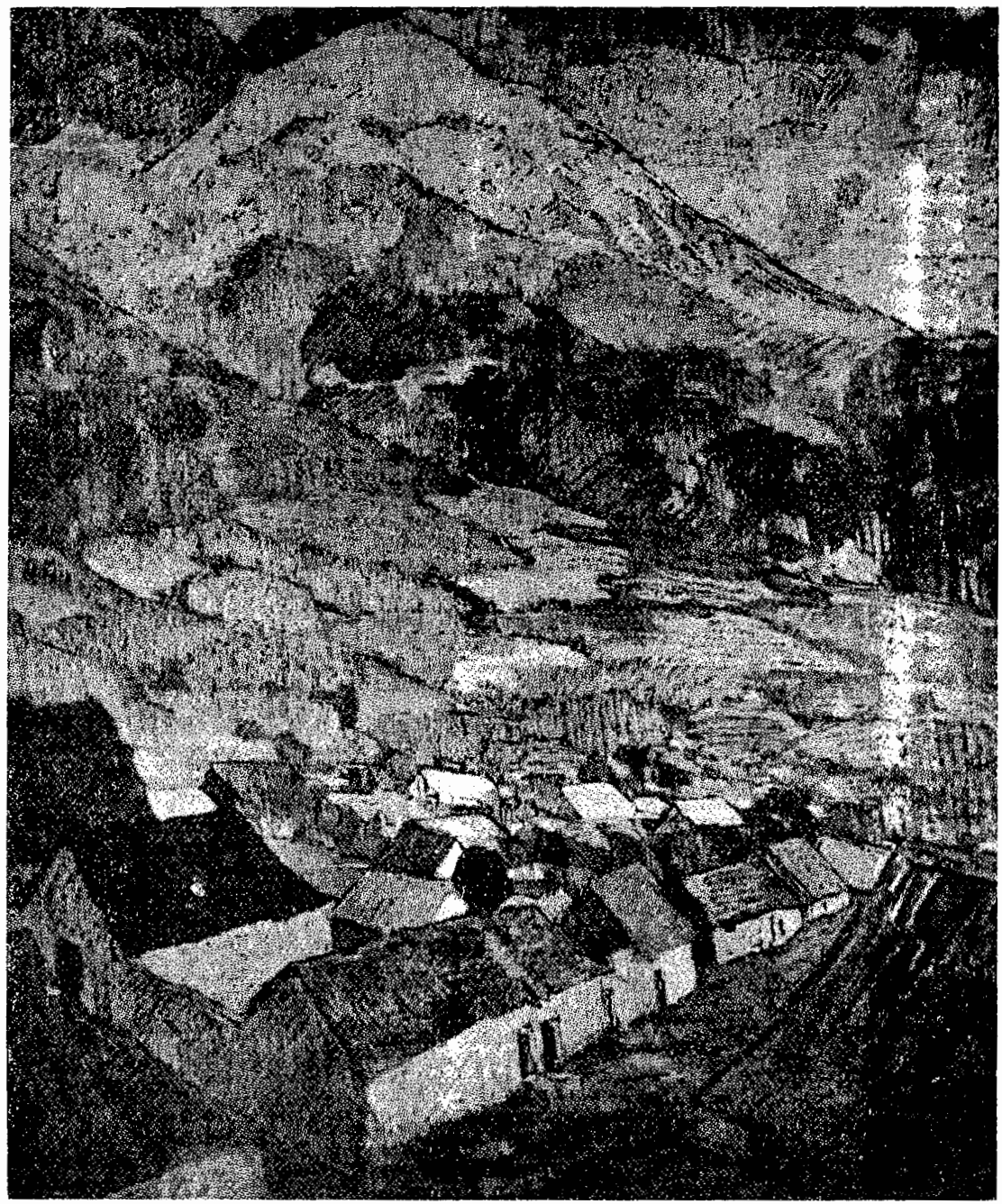

